\title{
CALLOVIAN AMMONITES FROM NORTHEASTERN IRAN
}

\author{
MAHMOUD REZA MAJIDIFARD \\ Research Institute for Earth Sciences, Geological Survey of Iran, Box 131851-1494, Tehran, Iran. \\ m_majidifard@yahoo.com
}

\begin{abstract}
The present paper includes the description of the Callovian ammonite fauna from the Dalichai Formation, eastern Alborz, Northeastern Iran. The following families are reported: Oppeliidae, Tulitidae, Macrocephalitidae, Pachyceratidae, Reineckeiidae, Perisphinctidae and Aspidoceratidae. Some of the taxa are recorded for the first time from Iran. Altogether, 211 specimens of ammonites belonging to 43 species, 21 genera, and seven families are described. Among the families, Phylloceratidae is the most abundant, followed by Perisphinctidae and Reineckeiidae. Pachyceratidae is the least common family. The ammonites represent six zones, i.e. Bullatus, Gracilis, Anceps, Coronatum, Athleta and Lamberti. Paleobiogeographically, the ammonite fauna is closely related to that of the sub-Mediterranean Province of the northwestern Tethys.
\end{abstract}

Keywords: Jurassic, Callovian, ammonites, taxonomy, Dalichai Formation, paleobiogeography.

RESUMO - O presente trabalho inclui as descrições sistemáticas da fauna de amonites do Calloviano da Formação Dalichai a leste de Alborz, no Nordeste do Irã. São reportadas as seguintes famílias: Oppeliidae, Tulitidae, Macrocephalitidae, Pachyceratidae, Reineckeiidae, Perisphinctidae e Aspidoceratidae. Alguns dos táxons são registrados pela primeira vez no Irã. No total, 211 espécimes de amonites pertencentes a 43 espécies, 21 gêneros e sete famílias são descritos. Entre as famílias, Phylloceratidae é a mais abundante, seguida por Perisphinctidae e Reineckeiidae. Pachyceratidae é a família menos comum. As amonites representam seis zonas, a seguir, Bullatus, Gracilis, Anceps, Coronatum, Athleta e Lamberti. Paleobiogeograficamente a fauna de amonites está intimamente relacionada com a da Província sub-mediterrânea do noroeste de Tétis.

Palavras-chave: Jurássico, Caloviano, amonites, taxonomia, Formação Dalichai, paleobiogeografia.

\section{INTRODUCTION}

The Middle and Upper Jurassic sedimentary successions of the Alborz Mountains in Northeastern Iran comprise two formations: Dalichai and Lar. The Callovian sedimentary succession belongs to the Dalichai Formation. The Dalichai Formation consists of alternations of greenish marl and light-grey to bluish-grey limestone. The Middle and Upper Jurassic rocks constitute a more or less continuous sequence, being confined by two tectonic events; one at the base, in the uppermost part of the Shemshak Formation (Bajocian), the Mid-Cimmerian Event (Seyed-Emami \& Alavi-Naini, 1990; Fürsich et al., 2009), the other one at the top (Early Cretaceous), the so-calle Late-Cimmerian Event (Sengör,1990). The lowermost unit constitutes the uppermost member of a siliciclastic and partly continental depositional sequence known as Shemshak Formation. It contains a fairly abundant ammonite fauna ranging in age from Aalenian to early Bajocian. This formation begins with transgressive sediments of late Bajocian age. The upper Bajocian to Tithonian rocks are predominantly carbonates, which represent a platform, slope and basin system (Majidifard, 2003, 2008). The Dalichai Formation is rich in ammonites, which have been described by Assereto et al. (1968), Seyed-
Emami et al. (1989, 1991, 1995, 2013), Seyed-Emami \& Schairer (2011), Schairer et al. (1992), Majidifard, (2003), and Dietze et al. (2014). The Golbini section of the Dalichai Formation is located $16 \mathrm{~km}$ north of Jajarm near the Golbini farm (quadrangle map of Kuh-e-Khurkhud, 1:250,000; coordinates $37^{\circ} 05^{\prime} 13^{\prime} \mathrm{N}, 56^{\circ} 44^{\prime} 41^{\prime \prime} \mathrm{E}$, Figure 1). The Tooy section is situated $4 \mathrm{~km}$ north of Tooy village (49 km west of Esferayen and $93 \mathrm{~km} \mathrm{SW}$ of Bojnourd; quadrangle map of Bojnourd, 1:250,000; coordinates $37^{\circ} 09^{\prime} 14^{\prime \prime} \mathrm{N}, 57^{\circ} 09^{\prime} 13^{\prime \prime} \mathrm{E}$; Figure 1). Based on ammonites, the Dalichai Formation ranges from the Upper Bajocian to Lower Tithonian. The top of the Dalichai Formation is diachronous at the studied sections. Thus, the age of the top of the formation is early Tithonian at the Golbini section and middle Kimmeridgian at the Tooy section.

\section{Stratigraphy of sections}

The type section of the Dalichai Formation (right bank of Dalichai River, $700 \mathrm{~m}$ below Pole e Ferdowsi (bridge) along the Tehran - Firuzkuh road, $113 \mathrm{~km}$ east of Tehran) consists of $107 \mathrm{~m}$ of light-grey to bluish-grey limestone with thin intercalations of marl. According to Steiger (1966), the thickness of the formation is about 50 to $120 \mathrm{~m}$ (average: $100 \mathrm{~m}$, reaching more than $300 \mathrm{~m}$ in the eastern Alborz). The 
lower boundary of the Dalichai Formation is an unconformity due to the Mid-Cimmerian tectonic event (Seyed-Emami \& Alavi-Naini,1990; Fürsich et al., 2009). In many areas, however, the upper boundary is gradational. In a few areas it is continuous but sharp, and followed by the Lar Formation (Seyed-Emami, 1975).

The ammonites described here come from a $96 \mathrm{~m}$ thick unit at Golbini, and an $80 \mathrm{~m}$ thick unit at Tooy. The lithology of the Callovian sedimentary successions consists of an alternation of marls and limestone characteristic of the Dalichai Formation (Figure 2). The Dalichai Formation at the Golbini section was measured north of Golbini with a total thickness of $454 \mathrm{~m}$. It ranges from the upper Bajocian to the lower Tithonian and can be subdivided, from bottom to top, into three members (Majidifard, 2008; Figure 2). It overlies diachronously and with a sharp contact the Shemshak Formation. Its boundary to the overlying ridge-forming Lar Formation is gradational.

Member 1. $105 \mathrm{~m}$ thick, consists of green-grey silty marls with small amounts of secondary gypsum. Pink limestones (floatstone) occur $84 \mathrm{~m}$ above the base of the member in beds varying from 20 to $60 \mathrm{~cm}$ in thickness. The fossils comprise siliceous sponges, bryozoans, Terebella lapilloides Münster, 1833, bivalves (?Anisocardia sp.), gastropods, (Obornella sp.), echinoderm debris, belemnites, microbial crusts, Tubiphytes, and ammonites (Strenoceras sp., Sphaeroceras tutthum Buckman, 1921, Garantiana (Orthogarantiana) cf. densicostata (Quenstedt, 1886), Oxycerites yeovilensis (Rollier, 1911). Oxycerites cf. oxus (Buckman, 1926) Bullatimorphites sp., Morphoceras multiforme Arkell, 1951, M. macrescens (Buckman, 1923), M. egrediens Wetzel, 1937, and Ebrayiceras cf. sulcatum (Zieten, 1830). The ammonite fauna indicates the upper Bajocian (Niortense-Garantiana zones) to lower Bathonian Zigzag Zone.

Member 2. It has a thickness of $211 \mathrm{~m}$ and consists of alternations of greyish-green marls, well-bedded greyish to yellow marly limestones and limestones (packstone). At some levels, the marly limestones and limestones contain abundant chert-nodules and the trace fossil Zoophycos. This member contains, apart from a few fossils such as bivalves (filaments, Protocardia), brachiopods (terebratulids), gastropods, echinoderm debris, belemnites, Neuropora sp., ostracods, radiolarians, sponge spicules, benthic foraminifers (Lenticulina sp., Ammobaculites coprolithoformis (Schwager, 1867), Spirillina Ehrenberg, 1843 rotaliids, nodosariids, miliolids), a rich ammonite fauna, indicative of the upper Bathonian (Retrocostatum Zone), lower Callovian (Gracilis Zone), middle Callovian (Anceps and Coronatum zones), upper Callovian (Lamberti Zone), and middle Oxfordian (Transversarium Zone).

Member 3. $138 \mathrm{~m}$ thick and consists of alternations of medium-bedded, grey to pinkish limestones (mudstone to packstone) with cherts, green-grey marls, and rare limestones (grainstone) with sharp erosional bases in beds varying from 30 to $80 \mathrm{~cm}$ in thickness. The macro- and microfauna is represented by bivalves (fragments), echinoderm debris, belemnites, ostracods, radiolarians, sponge spicules, benthic foraminifers (Lenticulina sp., Globuligerina sp., Ammobaculites sp., rotaliids, nodosariids and miliolids). In the upper part, the member contains microbial crusts, Terebella Linnaeus, 1767, Tubiphytes Maslov, 1956 and numerous ammonites indicative of the middle Oxfordian (Bifurcatus Zone), upper Oxfordian (Bimammatum Zone) and lower Kimmeridgian (Platynota Zone) and lower Tithonian (Richteri Zone).

At the Tooy section, the Dalichai Formation is $561 \mathrm{~m}$ thick, ranging from the Upper Bajocian to Kimmeridgian. It can be subdivided, from bottom to top, into three members (Majidifard, 2008, Figure 2):

Member $1.73 \mathrm{~m}$ thick and consists of green silty marls with belemnites and ammonites. It contains sponges, brachiopods, gastropods, echinoid spines, belemnites, benthic foraminifers (Nautiloculina sp., Lenticulina sp., nodosariids), ostracods and the ammonites Spiroceras orbignyi (Baugier \& Sauze, 1843) (Garantiana Zone), Spiroceras annulatum (Deshayes, 1831) (Niortense and Garantiana zones), Sphaeroceras tuttum Buckman, 1921 (Garantiana and Parkinsoni zones), Garantiana (Pseudogarantiana) dichotoma Bentz, 1928 (Garantiana Zone), and Parkinsonia parkinsoni (Sowerby, 1823) (Parkinsoni Zone), Bullatimorphites (Kheraiceras) bullatus (d'Orbigny, 1846) (lower to ?middle Bathonian), Cadomites (Polyplectites) dorni (Roche, 1939) (lower Bathonian), Homoeoplanulites (Homoeoplanulites) cf. bugesiacus (Dominjon, 1969) (Discus Zone), Homoeoplanulites (Parachoffatia) arkelli Mangold, 1970a (Discus Zone), and Homoeoplanulites sp.

Member 2. Thickness of $299 \mathrm{~m}$, consists of alternations of well-bedded greyish-green marls, greyish to yellow marly limestones (mudstone to packstone) and mediumbedded, grey limestones (mudstone to packstone) with chert nodules at some levels. Trace fossils include Zoophycos and Thalassinoides. The faunal content comprises bivalves (fragments, inoceramids, Entolium sp.), brachiopods (terebratulids, rhynchonellids), gastropods (Obornella sp.), Plagioecia sp., belemnites, nautiloids, ostracods, sponge spicules, radiolarians, echinoderm debris, benthic foraminifers (Globuligerina sp., Lenticulina sp., Ammobaculites coprolithiformis (Schwager, 1867), Spirillina, nodosariids, rotaliids, ophtalmiids, miliolids, textulariids), Laevaptychus, and abundant and diverse ammonites indicative of the Callovian (Macrocephalus, Patina, Anceps and Athleta zones) and Oxfordian (Cordatum, Bifurcatus, Planula and Transversarium zones).

Member 3. 189-m-thick, consists of green silty marl, alternating thin- to thick-bedded greenish-grey, well sorted, fine-grained sandstones and siltstone, alternating mediumbedded, cream-coloured to yellow limestones (wackestone) and marls, alternating thin- to thick-bedded greenishgrey, well sorted, fine-grained sandstones and siltstones and alternations of medium-bedded, cream-coloured to yellow limestones (wackestone) and marls. The sandstone beds occur between $0-26$ and $98-138 \mathrm{~m}$ above the base of the member.The sandstone beds are bioturbated; trace 


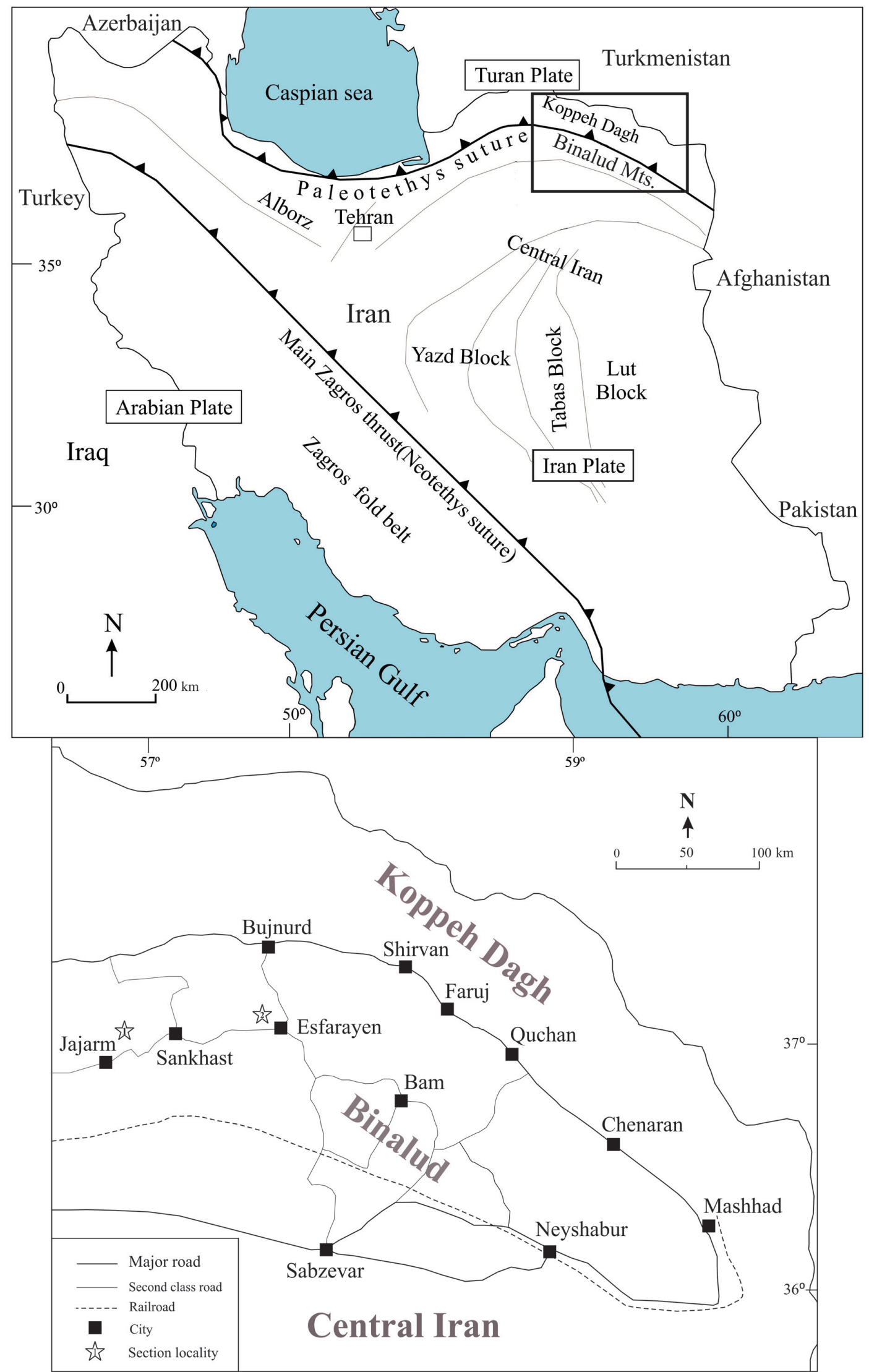

Figure 1. The position of the sections of the Middle and Upper Jurassic Dalichai Formation at Golbini (eastern Alborz) and Tooy (Binalud mountains), northeastern Iran. 
Sandstone
Limestone
Dolomite

U.B.- Ba.= upper Bajocian- lower Bathonian

Mid. Bath. - M. Oxfo.= middle Bathonian - Middle Oxfordian

M. Oxfo. - L. Th. $=$ middle Oxfordian - Lower Thitonian

\section{Golbini section}
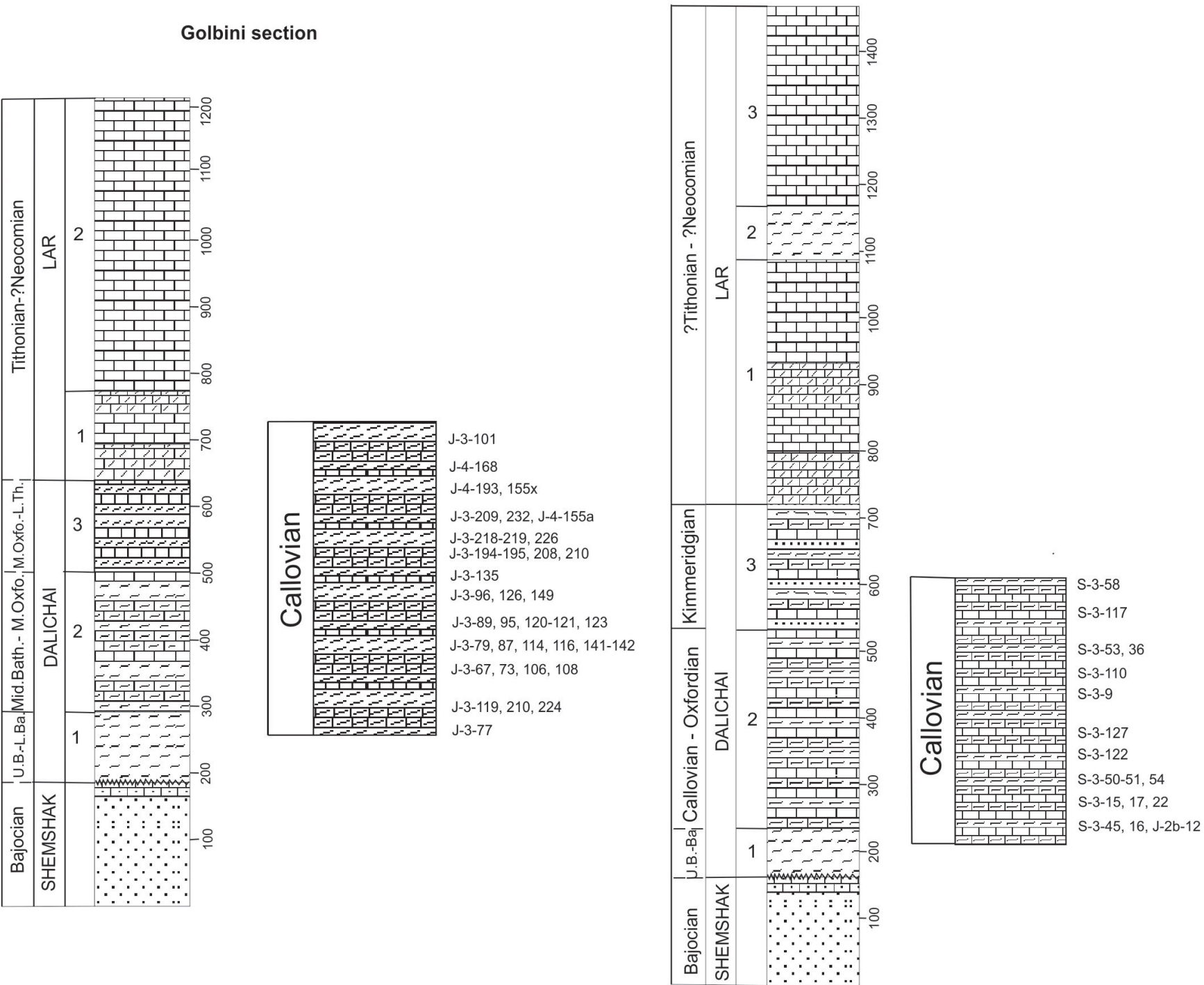

Figure 2. Stratigraphic logs of the Dalichai Formation at the two sections investigated.

fossils include Zoophycos and Rhizocorallium. Limestone (wackestone) in the lower part contains bivalves, belemnites and the ammonites Taramelliceras cf. kiderleni Berckhemer \& Hoelder, 1959, Sutneria eumela (d'Orbigny, 1847), Sutneria lorioli Zeiss, 1979 (Eudoxus Zone), and Physodoceras sp. which indicate the Kimmeridgian Eudoxus Zone.

\section{MATERIAL AND METHODS}

As far as permitted by the preservation of the specimens, measurements of the following parameters are given: diameter
(D) in mm, umbilical width (U), whorl height (H), whorl width (W), the latter all in \% of diameter; numbers of primary ribs per whorl (PR) and secondary ribs (SR). $[\mathbf{M}]=$ macroconch; $[\mathbf{m}]=$ microconch .

All specimens are figured in natural size, except otherwise indicated. The figured specimens are located at the Bayerische Staatssammlung für Paläontologie und Historische Geologie, Munich, Germany (prefix GZN2011I); the other letter-number combination indicates the locality $(\mathbf{J}=$ Golbini section; $\mathbf{S}=$ Tooy section) and the position in the section. 


\section{SYSTEMATIC PALEONTOLOGY}

Superfamily PHYLLOCERATOIDEA Zittel, 1884

Family PHYLLOCERATIDAE Zittel, 1884

Subfamily CALLIPHYLLOCERATINAE Spath, 1927

Calliphylloceras Spath, 1927

Calliphylloceras sp.

(Figures 3B-B', F)

Material. 18 specimens from Golbini (GZN2011I-J-4, 180-193, 240-243) and eight specimens from Tooy (GZN2011I-S-3, 25, 27, 29-31, 36-37, 43, 73), maximum diameter $58 \mathrm{~mm}$ and minimum $23 \mathrm{~mm}$.

Dimensions (in mm).

\begin{tabular}{ccccc}
\hline Specimen & $\mathrm{D}$ & $\mathrm{U} \%$ & $\mathrm{H} \%$ & $\mathrm{~W} \%$ \\
\hline $\begin{array}{c}\text { GZN2011I-S-3-36 } \\
\text { (incomplete } \\
\text { phragmocone) }\end{array}$ & 58 & 11 & 57 & 29 \\
$\begin{array}{c}\text { GZN2011I-J-4-186 } \\
\text { (incomplete } \\
\text { phragmocone) }\end{array}$ & 51 & 16 & 51 & 39 \\
$\begin{array}{c}\text { GZN2011I-J-4-191 } \\
\text { (incomplete } \\
\text { phragmocone) }\end{array}$ & 49 & 18 & 51 & 39 \\
$\begin{array}{c}\text { GZN2011I-J-4-193 } \\
\text { (incomplete body } \\
\text { chamber) }\end{array}$ & 35 & 16 & 56 & 39 \\
$\begin{array}{c}\text { GZN2011I-J-4-183 } \\
\text { (incomplete body } \\
\text { chamber) }\end{array}$ & 31 & 19 & 45 & 35 \\
$\begin{array}{c}\text { GZN2011I-J-4-192 } \\
\text { (incomplete body } \\
\text { chamber) }\end{array}$ & 24 & 21 & 54 & 42 \\
GZN2011I-J-4-185 \\
(incomplete \\
phragmocone)
\end{tabular}

Description. Specimen (J-4-183, 193) with incomplete body chamber and other specimens with incomplete phragmocones, maximum diameter $58 \mathrm{~mm}$ and minimum $23 \mathrm{~mm}$, involute phylloceratids with a smooth shell and steep, deep umbilicus. Suture line typically phylloceratid. Usually with five sigmoidal narrow constrictions on the last visible whorl. The constrictions start from the umbilical shoulder and terminate at the rounded venter.

Stratigraphic distribution: Calliphylloceras has a worldwide distribution, from the Hettangian to the Middle Albian. The present specimens come from the Callovian.

\section{Holcophylloceras Spath, 1927}

Holcophylloceras indicum (Lemoine, 1910)

(Figure 3G)

1910 Phylloceras mediterraneum Neumayr indica-Lemoine, p. 3, pl. 1, fig. 1.

1976 Holcophylloceras indicum sp. nov. - Joly, p. 239, pl. 22 , figs. $2-3,5$ pl. 23 , fig. 1 , pl. 25 , figs. $3-5$, pl. 26, figs. 2 , 5, pl. 27, figs. 1-2, 4-5.
Material. One specimen with diameter $80 \mathrm{~mm}$ and one fragment from Golbini (GZN2011I-J-4,155a,155b).

Dimensions (in mm).

\begin{tabular}{lcccc}
\hline Specimen & D & U\% & H\% & W\% \\
\hline $\begin{array}{c}\text { GZN2011I- } \\
\text { J-4-155a } \\
\text { (incomplete } \\
\text { phragmocone) }\end{array}$ & 80 & 12 & 56 & 28 \\
\hline
\end{tabular}

Description. A specimen with incomplete phragmocone, involute shell with five distinct and sigmoidal constrictions, which are narrow and shallow on the last visible whorl. Constrictions starting from the umbilical shoulder and terminating on the venter. Fine ribbing starts on the outer three-fourth of the flank and crosses the rounded venter.

Remarks. Based on the fine ribbing on the outer part of the whorl and the shape of the constrictions, the specimens closely match Holcophylloceras indicum.

Stratigraphic distribution: Holcophylloceras occurs worldwide from the Bajocian to the Aptian. The present specimens come from the middle Callovian, and the species is recorded for the first time from Iran.

\section{Ptychophylloceras Spath, 1927 \\ Ptychophylloceras sp. \\ (Figure 3D-D')}

Material. 28 specimens from Golbini (GZN2011I-J-4, 35, 102-105, 158-178, 266-267) and six specimens from Tooy (GZN2011I-S-3, 32-35, 40, 42, 57, 72), maximum diameter $85 \mathrm{~mm}$, minimum $24 \mathrm{~mm}$ and generally 40 to $51 \mathrm{~mm}$.

Dimensions (in mm).

\begin{tabular}{lllll}
\hline Specimens & $\mathrm{D}$ & $\mathrm{U} \%$ & $\mathrm{H} \%$ & $\mathrm{~W} \%$ \\
\hline $\begin{array}{c}\text { GZN2011I-S-3-33 } \\
\text { (incomplete } \\
\text { phragmocone) }\end{array}$ & 85 & 12 & 60 & 36 \\
$\begin{array}{c}\text { GZN2011I-S-3-32 } \\
\text { (incomplete } \\
\text { phragmocone) }\end{array}$ & 70 & 19 & 49 & 43 \\
$\begin{array}{c}\text { GZN2011I-J-4-168 } \\
\text { (incomplete }\end{array}$ & 56 & 15 & 55 & 37 \\
phragmocone) & & 16 & 45 & 39 \\
$\begin{array}{c}\text { GZN2011I-J-4-166 } \\
\text { (incomplete } \\
\text { phragmocone) }\end{array}$ & 51 & 16 & 52 & 26 \\
$\begin{array}{c}\text { GZN2011I-J-4-159 } \\
\text { (incomplete } \\
\text { phragmocone) }\end{array}$ & 50 & 19 & 53 & 25 \\
$\begin{array}{c}\text { GZN2011I-J-4-165 } \\
\text { (incomplete } \\
\text { phragmocone) }\end{array}$ & 47 & 17 & 51 & 42 \\
GZN2011I-J-4-172 \\
$\begin{array}{c}\text { (incomplete } \\
\text { phragmocone) }\end{array}$ & 47 & & & \\
$\begin{array}{c}\text { GZN2011I-S-3-40 } \\
\text { (incomplete } \\
\text { phragmocone) }\end{array}$ & 46 & & & \\
\hline
\end{tabular}




\begin{tabular}{ccccc}
\hline $\begin{array}{c}\text { GZN2011I-J-4-169 } \\
\text { (incomplete } \\
\text { phragmocone) }\end{array}$ & 46 & 17 & 50 & 39 \\
$\begin{array}{c}\text { GZN2011I-J-4-170 } \\
\text { (incomplete } \\
\text { phragmocone) }\end{array}$ & 40 & 17 & 52 & 37 \\
$\begin{array}{c}\text { GZN2011I-J-4-171 } \\
\text { (incomplete } \\
\text { phragmocone) }\end{array}$ & 30 & 17 & 53 & 36 \\
$\begin{array}{c}\text { GZN2011I-J-4-177 } \\
\text { (incomplete } \\
\text { phragmocone) }\end{array}$ & 26 & 19 & 54 & 42 \\
$\begin{array}{c}\text { GZN2011I-J-4-176 } \\
\text { (incomplete } \\
\text { phragmocone) }\end{array}$ & 24 & 12 & 54 & 46 \\
\hline
\end{tabular}

Description. Specimens with incomplete phragmocones, Shell involute, with rounded-quadrate whorl section, umbilicus deep. The narrow and shallow constrictions start out as concave near the umbilical shoulder and turn convex in a ventral direction. In some of the specimens (e.g. S-2-32) strong ridges are developed on the venter, in other specimens (e.g. S-2-33) broadly rounded venter are crossed by periodic fine labial ridges.

Stratigraphic distribution. The present specimens come from the Callovian.

Sowerbyceras Parona \& Bonarelli, 1895

Sowerbyceras sp.

(Figure 3A)

Material. 57 specimens from Golbini (GZN2011I-J-155x, 247a-e, 248a-g, 249a-k, 250a-g, 251a-1, 252a-i, 253a-1, 254-256, 280), 20 specimens from Tooy (GZN2011I-S-74, 142-160), maximum diameter $71 \mathrm{~mm}$ and minimum $28 \mathrm{~mm}$. Dimensions (in mm).

\begin{tabular}{ccccc}
\hline Specimens & $\mathrm{D}$ & $\mathrm{U} \%$ & $\mathrm{H} \%$ & $\mathrm{~W} \%$ \\
\hline $\begin{array}{c}\text { GZN2011I-J-5- } \\
\text { 248a (incomplete } \\
\text { phragmocone) }\end{array}$ & 71 & 18 & 48 & 25 \\
$\begin{array}{c}\text { GZN2011I-J-5- } \\
\text { 247a (incomplete } \\
\text { phragmocone) }\end{array}$ & 70 & 20 & 43 & 27 \\
$\begin{array}{c}\text { GZN2011I-J-5-249 } \\
\text { (incomplete }\end{array}$ & 60 & 27 & 47 & 30 \\
phragmocone) & & 30 & 41 & 31 \\
$\begin{array}{c}\text { GZN2011I-J-5- } \\
\text { 250a (incomplete } \\
\text { phragmocone) }\end{array}$ & 54 & 21 & 50 & 42 \\
$\begin{array}{c}\text { GZN2011I-J-5- } \\
248 \mathrm{a} \text { (incomplete } \\
\text { phragmocone) }\end{array}$ & 52 & 32 & 42 & 39 \\
$\begin{array}{c}\text { GZN2011I-J-4- } \\
\text { 155x (incomplete } \\
\text { phragmocone) }\end{array}$ & 28 & & & \\
\hline
\end{tabular}

Description. Shell moderately evolute with quadrate whorl cross-section. Umbilicus deep with the steep wall. Constrictions deep, wide, and sigmoidal starting at the umbilical shoulder and crossing prorsiradiate over the venter. Stratigraphic distribution. Worldwide in the OxfordianKimmeridgian. The present specimens come from the Callovian.
Nannolytoceras Buckman, 1905

Nannolytoceras sp.

(Figure 3H)

Material. One specimen with incomplete phragmocone from Tooy (GZN2011I-S-3, 9).

Description. Shell fairly wide with transverse elliptical to nearly quadrate whorl cross-section, umbilicus shallow. Shell surface smooth except for about three constrictions per whorl, which vary from oblique to prorsiradiate. The periodic constrictions are visible on both the internal mould and on the shell.

Stratigraphic distribution. The present specimen comes from the middle Callovian. According to Hoffmann (2010), the genus occurs in the Bajocian to the middle Bathonian of Europe (France, Hungary) and North Africa. The youngest representative comes from the middle Callovian of Crimea (Arkell et al., 1957; Stremoukhoff, 1923; Besnossov, 1958).

\section{Superfamily HAPLOCERATACEAE Zittel, 1884 Family OPPELIIDAE Bonarelli, 1894 Subfamily HECTICOCERATINAE Spath, 1925}

$$
\text { Hecticoceras Bonarelli, } 1893
$$

Subgenus Lunuloceras Bonarelli, 1893

\author{
Hecticoceras (Lunuloceras) aff. pseudopunctatum \\ (Lahusen, 1883) \\ (Figure 3J-J')
}

1883 Harpoceras pseudopunctatum - Lahusen, p. 73, pl. 11, figs. 10-12.

1939 Hecticoceras pseudopunctatum - Lahusen - Kuhn, p. 457, ix, v, fig. 9.

1956 Hecticoceras (Lunuloceras) pseudopunctatum (Lahusen) - Zeiss, p. 38, pl. 1, figs. 3-4.

1975 Lunuloceras (Lunuloceras) pseudopunctatum (Lahusen) - Lominadze, p. 75, pl. 7, figs. 6-9.

1961 Hecticoceras (Lunuloceras) pseudopunctatum (Lahusen) - Rangheard, p. 148, pl. 2, fig. 5-5a.

aff. 1984 Hecticoceras (Lunuloceras) pseudopunctatum (Lahusen, 1883) - Conze et al., p. 180, pl. 1, fig. 8.

1985 Lunuloceras (Lunuloceras) pseudopunctatum (Lahusen) - Schlegelmilch, p. 42, pl. 8, fig. 6.

1991 Hecticoceras (Lunuloceras) aff. pseudopunctatum (Lahusen)-Schairer et al., p. 65. pl. 1, fig. 3.

2000 Lunuloceras (Lunuloceras) pseudopunctatum (Lahusen) - Schairer et al., p. 55, fig. 13a-b.

Material. Eight specimens from Golbini (GZN2011I-J-3, 79-86), maximum diameter $79 \mathrm{~mm}$ and minimum $37 \mathrm{~mm}$, generally 45 to $57 \mathrm{~mm}$.

Dimensions (in mm). 


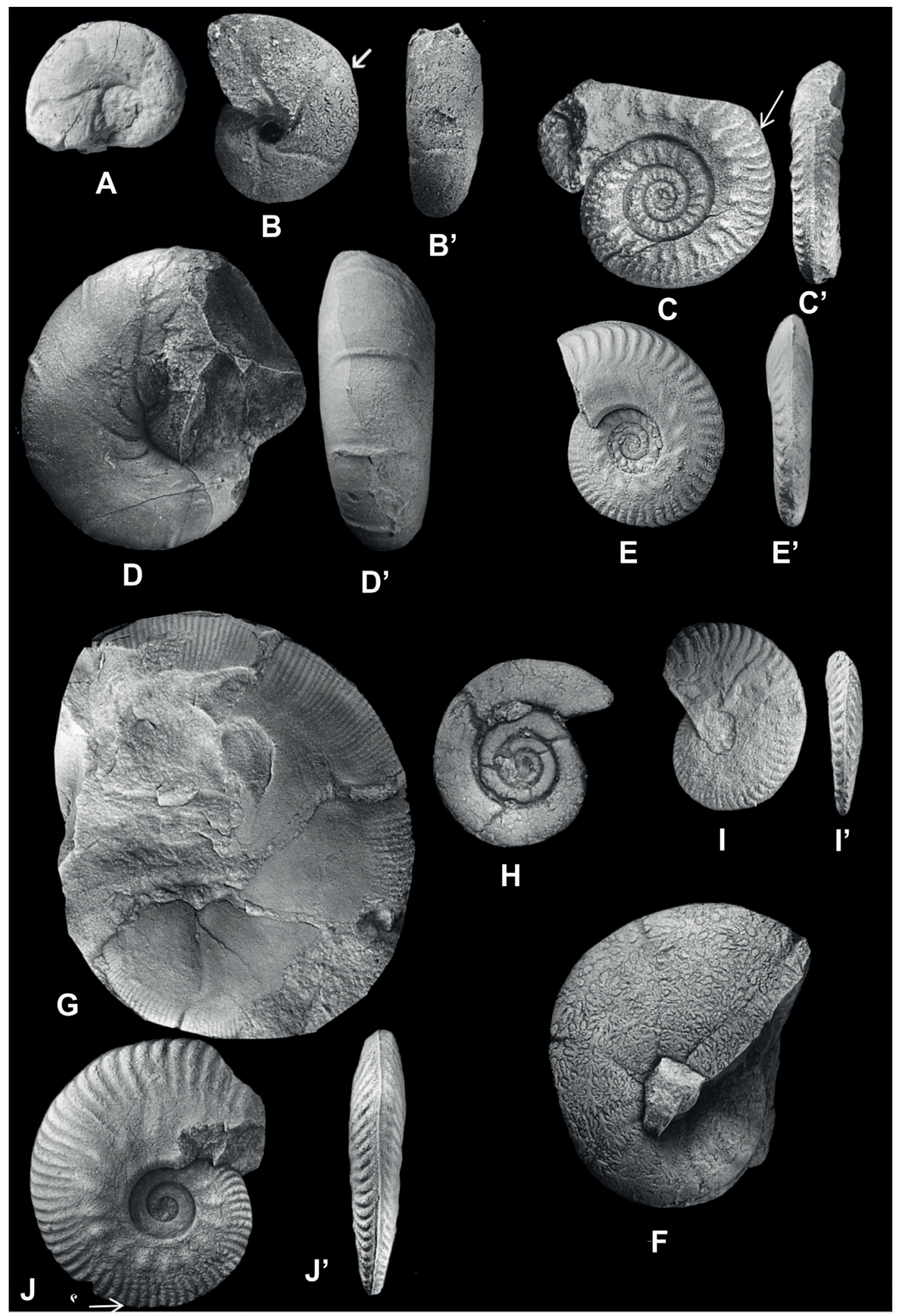

Figure 3. A, Sowerbyceras sp. (GZN2011I-J-4-155x), Golbini section. B-B', Calliphylloceras sp., specimen GZN2011I-J-4-193, a phragmocone with incomplete body chamber, Golbini section. C-C', Hecticoceras (Putealiceras) schalchi (Zeiss) (GZN2011I-J-3-67), a phragmocone with incomplete body chamber, Golbini section, Anceps Zone. D-D', Ptychophylloceras sp. (GZN2011I-J-4-168), Golbini section. E-E', Hecticoceras (Zieteniceras) evolutum (Lee) (GZN2011I-J-3-95) with incomplete phragmocone, Golbini section, middle Callovian. F, Calliphylloceras sp., specimen GZN2011I-S-3-36 with incomplete phragmocone, Tooy section. G, Holcophylloceras indicum (Lemoine) (GZN2011I-J-4-155a), Golbini section. H, Nannolytoceras sp. (GZN2011I-S-3-9), Tooy section; x1.5. I-I', Hecticoceras (Lunuloceras) cf. lunuloides (Kilian) (GZN2011I-J-3-87 with incomplete phragmocone, Golbini section, Anceps Zone. J-J', Hecticoceras (Lunuloceras) aff. pseudopunctatum (Lahusen) (GZN2011I-J-3-79), a phragmocone with incomplete body chamber, Golbini section, Callovian. Dimensions in the text. 


\begin{tabular}{ccccccc}
\hline Specimens & $\mathrm{D}$ & $\mathrm{U} \%$ & $\mathrm{H} \%$ & $\mathrm{~W} \%$ & $\mathrm{PR} / 2$ & $\mathrm{SR} / 2$ \\
\hline $\begin{array}{c}\text { GZN2011I-j-3-83 } \\
\text { (incomplete } \\
\text { phragmocone) }\end{array}$ & 79 & 27 & 47 & 19 & - & 30 \\
$\begin{array}{c}\text { GZN2011I-J-3-84 } \\
\text { (incomplete } \\
\text { phragmocone) }\end{array}$ & 57 & 24 & 45 & 21 & 7 & 25 \\
$\begin{array}{c}\text { GZN2011I-J-3-82 } \\
\text { (incomplete } \\
\text { phragmocone) }\end{array}$ & 53 & 34 & 39 & 17 & 7 & - \\
$\begin{array}{c}\text { GZN2011I-J-3-81 } \\
\text { (incomplete } \\
\text { phragmocone) }\end{array}$ & 53 & 25 & 46 & 13 & - & 26 \\
$\begin{array}{c}\text { GZN2011I-J-3-79 } \\
\text { (incomplete body } \\
\text { chamber) }\end{array}$ & 50 & 25 & 48 & 22 & 8 & 31 \\
$\begin{array}{c}\text { GZN2011I-J-3-80 } \\
\text { (incomplete } \\
\text { phragmocone) }\end{array}$ & 49 & 24 & 51 & 15 & 7 & 25 \\
$\begin{array}{c}\text { GZN2011I-J-3-86 } \\
\text { (incomplete } \\
\text { phragmocone) }\end{array}$ & 45 & 30 & 44 & 15 & - & 22 \\
\hline
\end{tabular}

Description. A specimen with incomplete body chamber (J3-79) and other specimens with incomplete phragmocones, shell with ovate whorl cross-section. Umbilicus deep with the steep umbilical wall. Primary ribs slightly bullate, distant and prorsiradiate, terminating at prominent nodes near midflank. The strong, prorsiradiate, bundled secondary ribs mainly bifurcate with some intercalatory ribs, which end at the distinct and narrow keel on the venter.

Remarks. The specimens differ from the specimen of Lahusen (1883), in having stronger nodes. They are similar to the material studied by Schairer et al. (1991) but differ from specimens described by Zeiss (1956), in having stronger ribs and nodes. The present specimens differ from specimens studied by Schlegelmilch (1985), in having slightly stronger ribs, from the specimens figured Conze et al. (1984) in having fainter ribs, and from the specimens studied by Rangheard (1961) in having blunter ribs. Most likely, they represent varieties of a single species.

Stratigraphic distribution. According to Zeiss (1959), the species ranges from the Callovian to the lower Oxfordian. The present specimens come from the Callovian.

\section{Hecticoceras (Lunuloceras) cf. lunuloides (Kilian 1899)} (Figure 3I-I')

1899 Harpoceras lunuloides Kilian - Kilian, p. 118.

cf. 1959 Hecticoceras (Lunuloceras) compressum (F.A. Quenstedt 1849) - Zeiss, p. 30.

cf. 1984 Hecticoceras (Lunuloceras) lunuloides Kilian 1899

- Conze et al., p. 179, pl. 1, fig. 14.

1991 Hecticoceras (Lunuloceras) cf. lunuloides (Kilian 1899)

- Schairer et al., p. 51, pl. 1, fig. 4.

1992 Hecticoceras (Lunuloceras) lunuloides (Kilian 1899)

- Schairer \& Zeiss, p. 231, pl. 1, fig. 4.

Material. Two specimens from Golbini (GZN2011I-J-3, 87-88), the first (J-3-87) is small $(\mathrm{D}=34 \mathrm{~mm})$; the second $(\mathrm{J}-3-88)$ is larger $(\mathrm{D}=40 \mathrm{~mm})$.
Dimensions (in mm).

\begin{tabular}{ccccccc}
\hline Specimens & $\mathrm{D}$ & $\mathrm{U} \%$ & $\mathrm{H} \%$ & $\mathrm{~W} \%$ & $\mathrm{PR} / 2$ & $\mathrm{SR} / 2$ \\
\hline $\begin{array}{c}\text { GZN2011I-J-3-88 } \\
\text { (incomplete } \\
\text { phragmocone) }\end{array}$ & 40 & 25 & 46 & 16 & - & 28 \\
$\begin{array}{c}\text { GZN2011I-J-3-87 } \\
\text { (incomplete } \\
\text { phragmocone) }\end{array}$ & 34 & 23 & 48 & 17 & - & 24 \\
\hline
\end{tabular}

Description. Specimens with incomplete phragmocone, shell compressed, involute, with trigonal whorl cross-section. Umbilicus shallow with steep umbilical wall and rounded shoulder. On the anterior part of the last whorl a faint rib starts at the umbilical margin and divides about mid-flank into two ribs. The secondary ribs end at a narrow keel and are slightly rursiradiate. Ribbing on the posterior part of the last whorl fine and dense, on the anterior part coarse and distant. The umbilical part of the whorl side is smooth other than fine, irregular striae. In contrast to the holotype, the ventral ribs are present only on the ventral third of the whorl side.

Remarks. The specimen figured by Quenstedt (1849, pl. 8, fig. 3) differs from the present specimens in having fine, dense ribs and a trigonal whorl section. The present material closely resembles the specimen figured by Schairer et al. (1991, pl. 1, fig. 4). The specimens differ from the specimen of Conze et al. (1984), in having stronger nodes. The specimen figured by Andal et al. (1968) as Hecticoceras (Lunuloceras) cf. Lunula (Reinecke) is very similar. Most likely, they represent varieties of a single species.

Stratigraphic distribution. According to Niederhöfer in Schairer et al. (1991), Hecticoceras (Lunuloceras) lunuloides occurs in the middle Callovian, Anceps Zone.

Subgenus Brightia Rollier, 1922

Hecticoceras (Brightia) solinophorum Bonarelli, 1893 (Figure 4B-B')

1893 Hecticoceras (Lunuloceras) nodosum Bonar. var. solinophorum n. - Bonarelli, p. 94.

1991 Hecticoceras (Brightia) aff. solinophorum Bonarelli Schairer et al., p. 50, pl. 1, fig. 2.

Material. Two specimens from Golbini (GZN2011I-J-3, 96-97), the first (J-3-96) is small $(\mathrm{D}=31 \mathrm{~mm})$; the second (J-3-97) is larger $(\mathrm{D}=42 \mathrm{~mm})$.

\section{Dimensions (in mm).}

\begin{tabular}{|c|c|c|c|c|c|c|}
\hline Specimens & D & U\% & $\mathrm{H} \%$ & W\% & $\mathrm{PR} / 2$ & $\mathrm{SR} / 2$ \\
\hline $\begin{array}{l}\text { GZN2011I-J-3-97 } \\
\text { (incomplete } \\
\text { phragmocone) }\end{array}$ & 42 & 34 & 40 & 15 & - & 18 \\
\hline $\begin{array}{l}\text { GZN2011I-J-3-96 } \\
\text { (incomplete } \\
\text { phragmocone) }\end{array}$ & 31 & 43 & 40 & 17 & - & - \\
\hline
\end{tabular}

Description. Specimens with incomplete phragmocones, moderately evolute, flanks flat, venter narrow, whorl crosssection high-ovate, umbilicus shallow, with the steep wall. The strong, falcate and prorsiradiate primaries begin about 
mid-flank and terminate at a narrow and trigonal keel on the venter. Ribs on inner whorls smooth. Towards the aperture primaries are strong and distant.

Remarks. The present specimens differ from the specimens studied by Quenstedt (1858) in having stronger ribs, and from the specimens figured by Schairer et al. (1991) in having fainter ribs. Most likely, they represent varieties of a single species.

Stratigraphic distribution. The present specimens come from the middle Callovian, while according to Zeiss (1959), the species ranges from the middle Callovian to the lower Oxfordian.

\section{Subgenus Putealiceras Buckman, 1922}

Hecticoceras (Putealiceras) metomphalum (Bonarelli, 1893)

(Figure 4A-A')

1893 Hecticoceras (Lunuloceras) metomphalum sp. nov. Bonarelli, p. 90.

1911 Hecticoceras metomphalum Bonar. var. multicostata nob. - Tsytovitch, p. 62, pl. 5, figs. 13-14.

1939 Hecticoceras metomphalum Bonarelli - Kuhn, p. 455, pl. 5 , fig. 2.

1956 Hecticoceras (Rossiensiceras) metomphalum (Bonarelli) -Zeiss, p. 107, pl. 2, fig. 7.

1975 Putealiceras (Putealiceras) metomphalum multicostatum (Tsytovitch) - Lominadze, p. 37, pl. 2, figs. 6-7.

1976 Hecticoceras (Brightia) metomphalum Bonarelli Rocha, p. 115, pl. 2, fig. 21.

1984 Hecticoceras (Rossiensiceras) metomphalum (Bonarelli) - Conze et al., p. 176, pl. 1, figs. 3-5.

1985 Hecticoceras (Putealiceras) metomphalum BonarelliSchlegelmilch, p. 42, pl. 8, fig. 3.

2013 Hecticoceras (Rossiensiceras) gr metomphalum Bonarelli - Seyed-Emami et al., p. 50, fig. 5f.

Material. Five specimens and one fragment from Golbini (GZN2011I-J-3, 73-78, 78a, 79); one specimen from Tooy (GZN2011I-S-3, 108), maximum diameter $51 \mathrm{~mm}$ and minimum $33 \mathrm{~mm}$, generally 42 to $51 \mathrm{~mm}$.

Dimensions (in mm).

\begin{tabular}{ccccccc}
\hline Specimens & $\mathrm{D}$ & $\mathrm{U} \%$ & $\mathrm{H} \%$ & $\mathrm{~W} \%$ & $\mathrm{PR} / 2$ & $\mathrm{SR} / 2$ \\
\hline $\begin{array}{c}\text { GZN2011I-j-3-73 } \\
\text { (incomplete } \\
\text { phragmocone) }\end{array}$ & 51 & 33 & 41 & 17 & 10 & 26 \\
$\begin{array}{c}\text { GZN2011I-J-3-79 } \\
\text { (incomplete } \\
\text { phragmocone) }\end{array}$ & 48 & 35 & 40 & 19 & 11 & 26 \\
$\begin{array}{c}\text { GZN2011I-J-3-74 } \\
\text { (incomplete } \\
\text { phragmocone) }\end{array}$ & 42 & 33 & 40 & 21 & 10 & 29 \\
$\begin{array}{c}\text { GZN2011I-J-3-78 } \\
\text { (incomplete } \\
\text { phragmocone) }\end{array}$ & 33 & 36 & 36 & 18 & - & - \\
\hline
\end{tabular}

Description. Specimens with incomplete phragmocones. This taxon has a rather large intraspecific morphological variability, ranging from compressed and involute forms up to evolute and heavily ornamented forms. Whorl cross-section high-ovate, umbilicus deep, with the steep wall. Primary ribs beginning close to the umbilical shoulder, terminating on the flank about one-third up at prominent lateral tubercles. Secondaries strong, prorsiradiate, slightly falcate and moderately bifurcating with some intercalatory ribs. They end at the fine keel on the venter.

Remarks. Several authors proposed subdivisions at the subspecies level (Zeiss, 1956), introducing Hecticoceras (Lunuloceras) metomphalum multicostatum Tsytovitch (1911) for compressed forms with numerous external ribs, or Hecticoceras (Lunuloceras) metomphalum acuticosta Tsytovitch (1911) for the forms with strong internal ribs. Compared to the holotype, the specimens are more evolute. The specimen clearly belongs to Hecticoceras (Putealiceras) metomphalum, which shows a great variability with regard to ribbing pattern and umbilical width. The tubercles and ribs present in the specimens are distinctly more densely spaced and more numerous than in Hecticoceras (Rossiensiceras) metomphalum Bonarelli, 1893. According to the ornamentation, the present specimens most closely resembles the subspecies Hecticoceras (Rossiensiceras) metomphalum multicostata Tsytovitch, 1911 (Tsytovitch, 1911: pl.5, fig. 12; Zeiss, 1956: pl. 2, fig. 7) and Hecticoceras (Rossiensiceras) metomphalum suevum Bonarelli in Tsytovitch, 1911 (Tsytovitch, 1911: pl. 5, figs. 7, 8, 10). However, the later is much more evolute. It may be noted that the subgenus Rossiensiceras Gerard \& Contaut, 1936 is considered synonymous to Putealiceras by Arkell (1956) and Schlegelmilch (1985).

Stratigraphic distribution. According to Tsytovitch (1911), the species occurs in the middle Callovian (Anceps Zone) and middle Callovian Jason Zone (Zeiss, 1956, 1959; Thierry et al., 1997).

\section{Hecticoceras (Putealiceras) schalchi Zeiss, 1956} (Figure 3C-C')

1956 Hecticoceras (Putealiceras) schalchi sp. nov. - Zeiss, p. 67 , pl. 3, fig. 4.

1961 Hecticoceras (Putealiceras) schalehi Zeiss - Rangheard, p. 160 , pl. 4 , fig. 3 .

1975 Putealiceras (Zieteniceras) schalchi Zeiss - Lominadze, p. 63 , pl. 6, figs. 5-6.

Material. Five specimens and one fragment from Golbini (GZN2011I-J-3, 67-72), maximum diameter $43 \mathrm{~mm}$ and minimum $25 \mathrm{~mm}$, generally 30 to $33 \mathrm{~mm}$.

Dimensions (in mm).

\begin{tabular}{ccccccc}
\hline Specimen & $\mathrm{D}$ & $\mathrm{U} \%$ & $\mathrm{H} \%$ & $\mathrm{~W} \%$ & $\mathrm{PR} / 2$ & $\mathrm{SR} / 2$ \\
\hline $\begin{array}{c}\text { GZN2011I-J-3-67 } \\
\text { (incomplete body } \\
\text { chamber) }\end{array}$ & 43 & 45 & 34 & & 10 & 26 \\
$\begin{array}{c}\text { GZN2011I-J-3-69 } \\
\text { (incomplete } \\
\text { phragmocone) }\end{array}$ & 33 & 35 & 42 & 21 & 8 & \\
$\begin{array}{c}\text { GZN2011I-J-3-68 } \\
\text { (incomplete } \\
\text { phragmocone) }\end{array}$ & 31 & 35 & 42 & & 8 & 25 \\
\hline
\end{tabular}



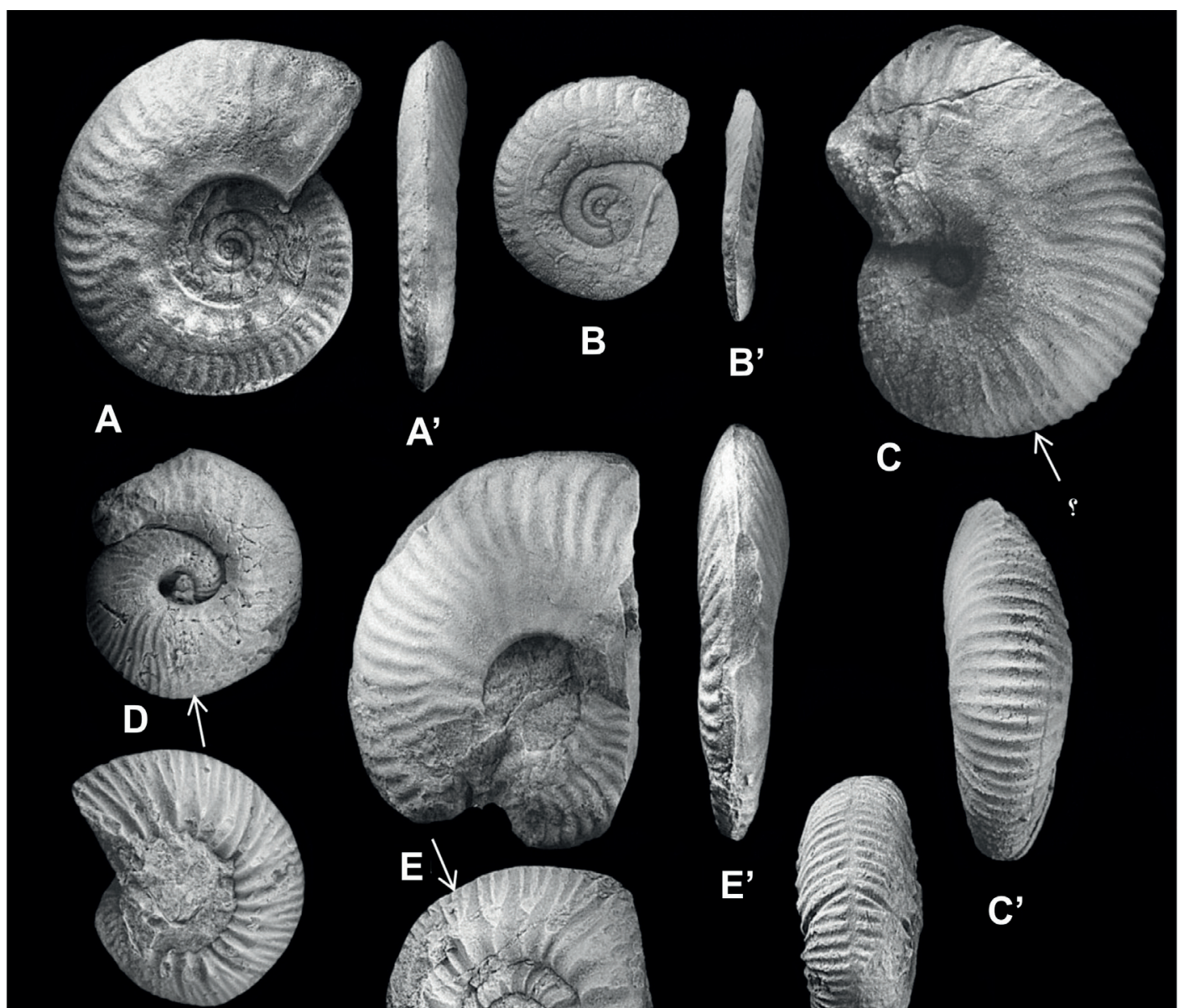

E

F

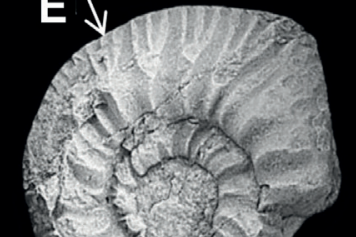

E'
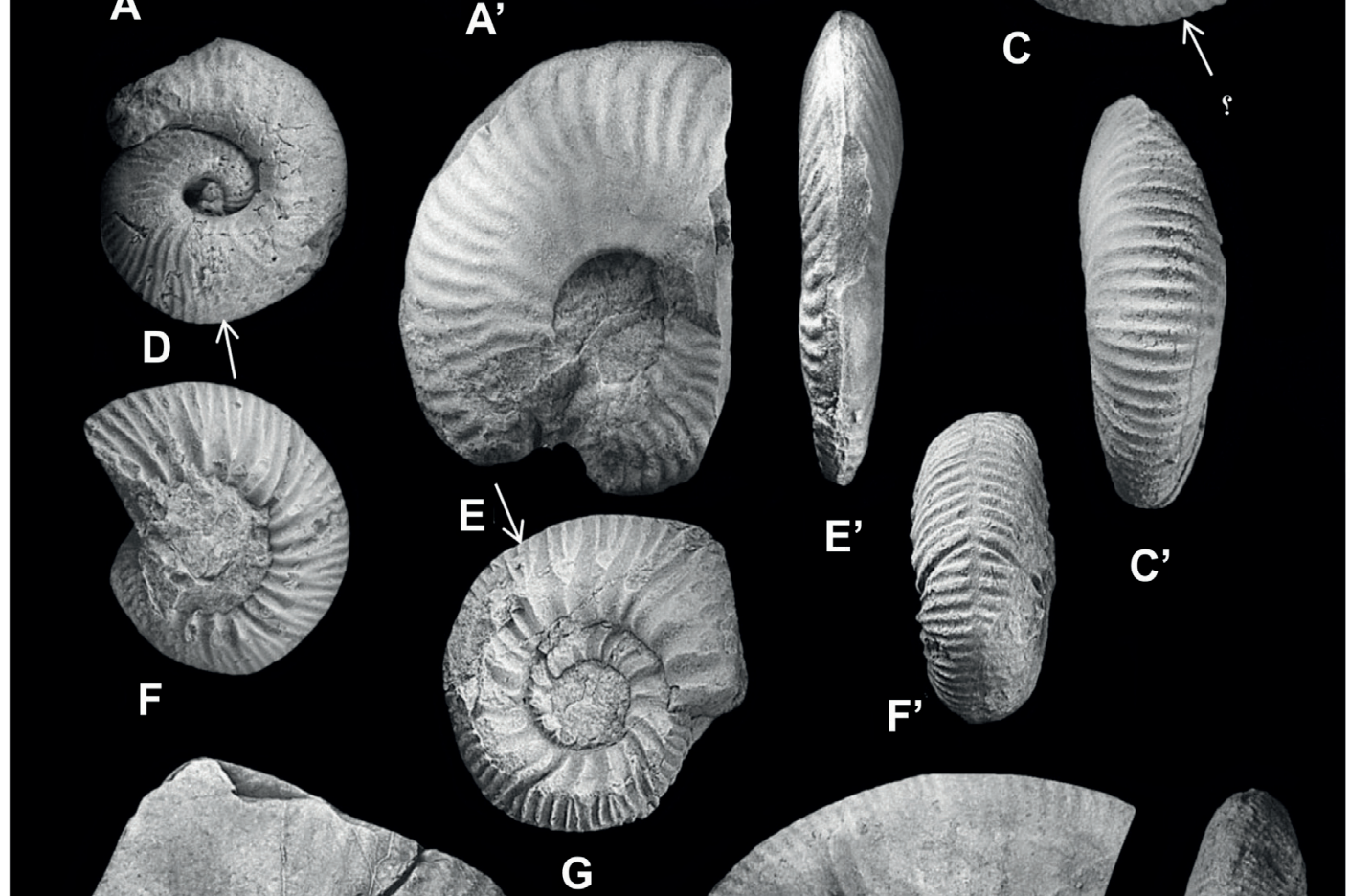


\begin{tabular}{ccccccc}
\hline $\begin{array}{c}\text { GZN2011I-J-3-72 } \\
\text { (incomplete } \\
\text { phragmocone) }\end{array}$ & 30 & 40 & 37 & 20 & 7 & 20 \\
$\begin{array}{c}\text { GZN2011I-J-3-71 } \\
\text { (incomplete } \\
\text { phragmocone) }\end{array}$ & 25 & 40 & 34 & 22 & 10 & 25 \\
\hline
\end{tabular}

Description. A specimen with incomplete body chamber (J-3-67), and specimens (J-3-68-69, 72, 71) with incomplete phragmocones, whorl cross-section ovate, umbilicus shallow with steep wall, flanks flat, venter fairly narrow. Radiate primary ribs beginning at the umbilical margin and ending at about one-third of flank height at prominent, conical lateral tubercles. From there, they mainly bifurcate with some intercalators. Concave secondary ribs terminating at a narrow and distinct keel on the venter. Secondary ribs denser than primaries. Ribs on inner whorls finer than those on outer whorls. Secondary on outer whorls coarse, strong and bullate than primary ribs. Towards the aperture secondary are strong and distant bullate than primary ribs. Ribbing on outer whorls stronger, coarser, and more distant than on inner whorls. Ribbing denser at the posterior part of the last whorl.

Remarks. The present specimens resemble the holotype (Zeiss, 1956), and the material figured by Rangheard (1961). The specimen figured by Lominadze (1975), differs from the present specimens in having finer ribs.

Stratigraphic distribution. According to Tsytovitch (1911), the species occurs in the middle Callovian (Anceps Zone), and is recorded for the first time from Iran.

\section{Subgenus Zieteniceras Zeiss, 1956}

\section{Hecticoceras (Zieteniceras) zieteni Tsytovitch, 1911} (Figure 4E-E')

1911 Hecticoceras zieteni sp. nov. - Tsytovitch, p. 25, pl. 1, fig. 2.

1956 Hecticoceras (Zieteniceras) zieteni (Tsytovitch) - Zeiss, p. 105, pl. 1, fig. 17.

1961 Hecticoceras (Zieteniceras) zieteni Tsytovitch Rangheard, p. 141, pl. 1, fig. 7.

1975 Putealiceras (Zieteniceras) zieteni (Tsytovitch) Lominadze, p. 52, pl. 4, figs. 5, 7, pl. 5, fig. 1.

1985 Hecticoceras (Zieteniceras) zieteni Tsytovitch Schlegelmilch, p. 162, pl. 6, fig. 5.

2009 Hecticoceras (Prohecticoceras) gr. zieteni (Tsytovitch, 1911) - Schlögl et al., p. 63, pl. 5, fig. 15.

Material. Two specimens and one fragment from Golbini (GZN2011I-J-3, 89-91) the first (J-3-91) is small (D = 49 $\mathrm{mm})$; the second $(\mathrm{J}-3-89)$ is larger $(\mathrm{D}=53 \mathrm{~mm})$.

Dimensions (in mm).

\begin{tabular}{ccccccc}
\hline Specimens & $\mathrm{D}$ & $\mathrm{U} \%$ & $\mathrm{H} \%$ & $\mathrm{~W} \%$ & $\mathrm{PR} / 2$ & $\mathrm{SR} / 2$ \\
\hline $\begin{array}{c}\text { GZN2011I-J-3-89 } \\
\text { (incomplete } \\
\text { phragmocone) }\end{array}$ & 53 & 28 & 46 & 23 & 11 & \\
\hline $\begin{array}{c}\text { GZN2011I-J-3-91 } \\
\text { (incomplete } \\
\text { phragmocone) }\end{array}$ & 49 & 34 & 42 & 24 & 11 & 24 \\
\hline
\end{tabular}

Description. Specimens with incomplete phragmocones, moderately involute, venter fairly narrow, whorl cross-section high-ovate, flank relatively flat and ribbing relatively coarse, relatively large and keel venter, and falcoid ribbing, umbilicus deep with steep wall and rounded shoulder. The strong, radiate to slightly prorsiradiate primary ribs begin at the umbilical margin and divide about mid-flank into two secondary ribs which, together with some intercalated ribs. They end at the distinct keel on the venter. Towards the aperture, distant ribs, stronger and whorl height increasing.

Remarks. The present material is very similar to the holotype, but differs from the specimens studied by Lominadze (1975, especially the figured in pl. 5, fig. 1), in having coarser and sharper ribs. This species shows, however, a large intraspecific variability encompassing also forms similar to the described specimen.

Stratigraphic distribution. The specimens from Iran occur in the Callovian Anceps Zone. The species was established by Tsytovitch (1911), based on material from the middle Callovian Anceps Zone. It has also been recorded from the middle Callovian Coronatum Zone and the Macrocephalus/ Anceps zones (Lemoine, 1932) and is recorded for the first time from Iran.

\section{Hecticoceras (Zieteniceras) evolutum Lee, 1905} (Figure 3E-E')

1905 Hecticoceras evolutus - Lee, p. 21, pl .1, fig. 6. 1911 Hecticoceras evolutum Lee - Tsytovitch, p. 21, pl. 2, fig. 9.

1956 Hecticoceras (Zieteniceras) evolutum Lee - Zeiss, p. 105, pl. 1, fig. 19.

1985 Hecticoceras (Zieteniceras) evolutum Lee Schlegelmilch, p. 163, pl. 6, fig. 7.

Material. Three specimens and one fragment from Golbini (GZN2011I-J-3, 93-95), the first (J-3-95) is small ( $\mathrm{D}=40$ $\mathrm{mm})$; the second $(\mathrm{J}-3-93)$ is medium $(\mathrm{D}=43 \mathrm{~mm})$; the third (J-3-94) is larger sized $(\mathrm{D}=49)$.

\section{Dimensions (in mm).}

\begin{tabular}{lcccccc}
\hline Specimens & $\mathrm{D}$ & $\mathrm{U} \%$ & $\mathrm{H} \%$ & $\mathrm{~W} \%$ & $\mathrm{PR} / 2$ & $\mathrm{SR} / 2$ \\
\hline $\begin{array}{c}\text { GZN2011I-J-3-94 } \\
\text { (incomplete } \\
\text { phragmocone) }\end{array}$ & 49 & 32 & 42 & 23 & 8 & 22 \\
$\begin{array}{c}\text { GZN2011I-J-3-93 } \\
\text { (incomplete } \\
\text { phragmocone) }\end{array}$ & 43 & 38 & 42 & 23 & 9 & 24 \\
$\begin{array}{c}\text { GZN2011I-J-3-95 } \\
\text { (incomplete } \\
\text { phragmocone) }\end{array}$ & 40 & 32 & 43 & 22 & 8 & 23 \\
\hline
\end{tabular}

Description. Specimens with incomplete phragmocones, flanks flat, venter narrow, moderately involute, whorl cross-section high-ovate, umbilicus shallow with steep wall and rounded shoulder. Primaries bullate and prorsiradiate, beginning at the umbilical margin and dividing about mid-flank into two to three rursiradiate secondaries which, 
together with some intercalated ribs, end at the fine keel on the venter. Secondary ribs denser than primary ones. Towards the aperture, ribs distant, stronger and whorl height increasing. Ribs on inner whorls finer than those on outer whorls. Secondary ribs stronger and distinct than primaries.

Remarks. The present specimens are very similar to the holotype, but differ from the specimen figured by Zeiss (1959) in having coarser and stronger primary ribs, and from the specimens figured by Schlegelmilch (1985) in having bullate primaries ribs.

Stratigraphic distribution. Middle Callovian (Zeiss, 1959); the species is recorded for the first time from Iran.

\section{Superfamily STEPHANOCERATOIDEA Neumayr, 1875 Family TULITIDAE Buckman, 1921}

Bullatimorphites Buckman, 1921

Subgenus Bomburites Arkell, 1952

Bullatimorphites (Bomburites) cf. microstoma

(d'Orbigny, 1846)

(Figure 4D)

cf. 1846 Ammonites microstoma - d'Orbigny, p. 413, pl. 129, figs. 3-4.

cf. 1887 Ammonites microstoma (d'Orbigny) - Quenstedt, p. 661, pl. 78, figs. 3, 4, 6 .

cf. 1958 Bullatimorphites ? (Bomburites) microstoma (d'Orbigny) - Westermann, p. 66, pl. 22, fig. 3.

cf. 1971 Bullatimorphites (Bomburites) microstoma (d'Orbigny) - Hahn, pl. 9, fig. 8.

cf. 1985 Bullatimorphites (Bomburites) microstoma (d'Orbigny) - Schlegelmilch, p. 135, pl. 52, fig. 8.

Material. One specimen from Tooy with diameter $35 \mathrm{~mm}$ (GZN2011I-S-3, 45).

Dimensions (in mm).

\begin{tabular}{ccccccc}
\hline Specimen & $\mathrm{D}$ & $\mathrm{U} \%$ & $\mathrm{H} \%$ & $\mathrm{~W} \%$ & $\mathrm{PR} / 2$ & $\mathrm{SR} / 2$ \\
\hline $\begin{array}{c}\text { GZN2011I-S-3-45 } \\
\text { (incomplete body } \\
\text { chamber) }\end{array}$ & 35 & 28 & 37 & 43 & 14 & \\
\hline
\end{tabular}

Description. A specimen with incomplete body chamber, mostly in poor state of preservation. Inner and middle whorls with narrow umbilicus, the last whorl, which is the body chamber, is eccentrically coiled, with widely opening umbilicus. The features of the aperture cannot be seen because there is no completely preserved specimen in the material. Shell involute, inflated, venter broad, umbilical wall vertical. Primary ribs starting at the umbilical margin. Secondary ribs irregular, some starting around the umbilical margin, others halfway or two-thirds up the flank. In addition, some ribs are single, yet others sinuous which, together with some intercalated ribs, continue towards the venter. Secondary ribs stronger and denser than primaries. Ribs on the inner part in the last visible whorl prorsiradiate and on the outer part moderately rectiradiate.
Remarks. The present specimen resembles a specimen of Bullatimorphites (Bomburites) suevicus illustrated in Hahn (1971, pl. 8, fig. 8), but differs in having sinuous and regular ribs. The specimen figured in Hahn (1971, pl. 9, fig. 8) has stronger primary ribs. Westermann (1958, pl. 22, fig. $3)$ 's specimen differs by the shape of its umbilicus, and the figured in Quenstedt (1887, pl. 78, figs. 3-4, 6), display some sinuous ribs.

Stratigraphic distribution. Lower Callovian, Bullatus Zone (Hahn, 1971); the species is recorded for the first time from Iran.

Subgenus Kheraiceras Spath, 1924

Bullatimorphites (Kheraiceras) sp. (Figure 5B-B')

Material. One fragment from Golbini (GZN2011I-J-3, 37). Description and remarks. A specimen with incomplete phragmocone, shell fat and inflated, broadly convex venter. Involute globular sperocone with very small umbilicus and suboval whorl section with rounded shoulder. Venter with rectiradiate, strong, distant and coarse ribs. Since only the ventral area is visible, a specific identification is not possible. The specimen resembles, however, Kheraiceras cf. K. bullatum as figured by Seyed-Emami et al. (1991, pl. 4, fig. 1). Its coarse ribs and broad venter are also similar to Bullatimorphites (Kheraiceras) hannoveranus Dietl (1994, pl. 1, fig. 2).

Stratigraphic distribution. The specimen comes from the lower Callovian.

Family MACROCEPHALITIDAE Buckman, 1922

Macrocephalites Zittel, 1884

Subgenus Macrocephalites Zittel, 1884

Macrocephalites (Macrocephalites) jacquoti

(Douvillé, 1912)

(Figure 5C-C')

1994 Macrocephalites (Macrocephalites) jacquoti (Douvillé 1912) - Dietl, p. 13, pl. 2, fig. 4, pl. 4, figs. 1-3, pl. 5, fig. 1. 1998 Macrocephalites (Macrocephalites) jacquoti (Douvillé 1912) - Dietl \& Gygi, pl. 3.

2009 Macrocephalites jacquoti Douvillé - Mitta, p. 52, pl. 7, figs. 1-3.

Material. 3 fragments from Golbini (GZN2011I-J-3, 38-40), and 1 fragment from Tooy (GZN2011I-S-3-16).

Description. A specimen with incomplete phragmocone, shell inflated and large-sized, umbilicus narrow and moderately narrow, with a vertical wall and a rounded shoulder, whorl cross-section oval, venter rounded and broad. The prorsiradiate primaries divide at about one-third of the height of the flank into two and seldom into three prorsiradiate 

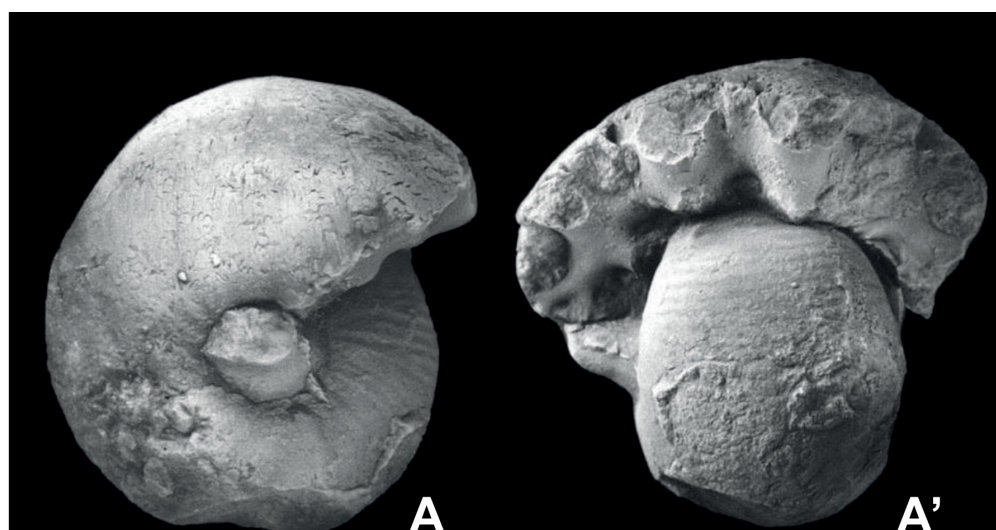

A

\section{$\mathbf{A}^{\prime}$}
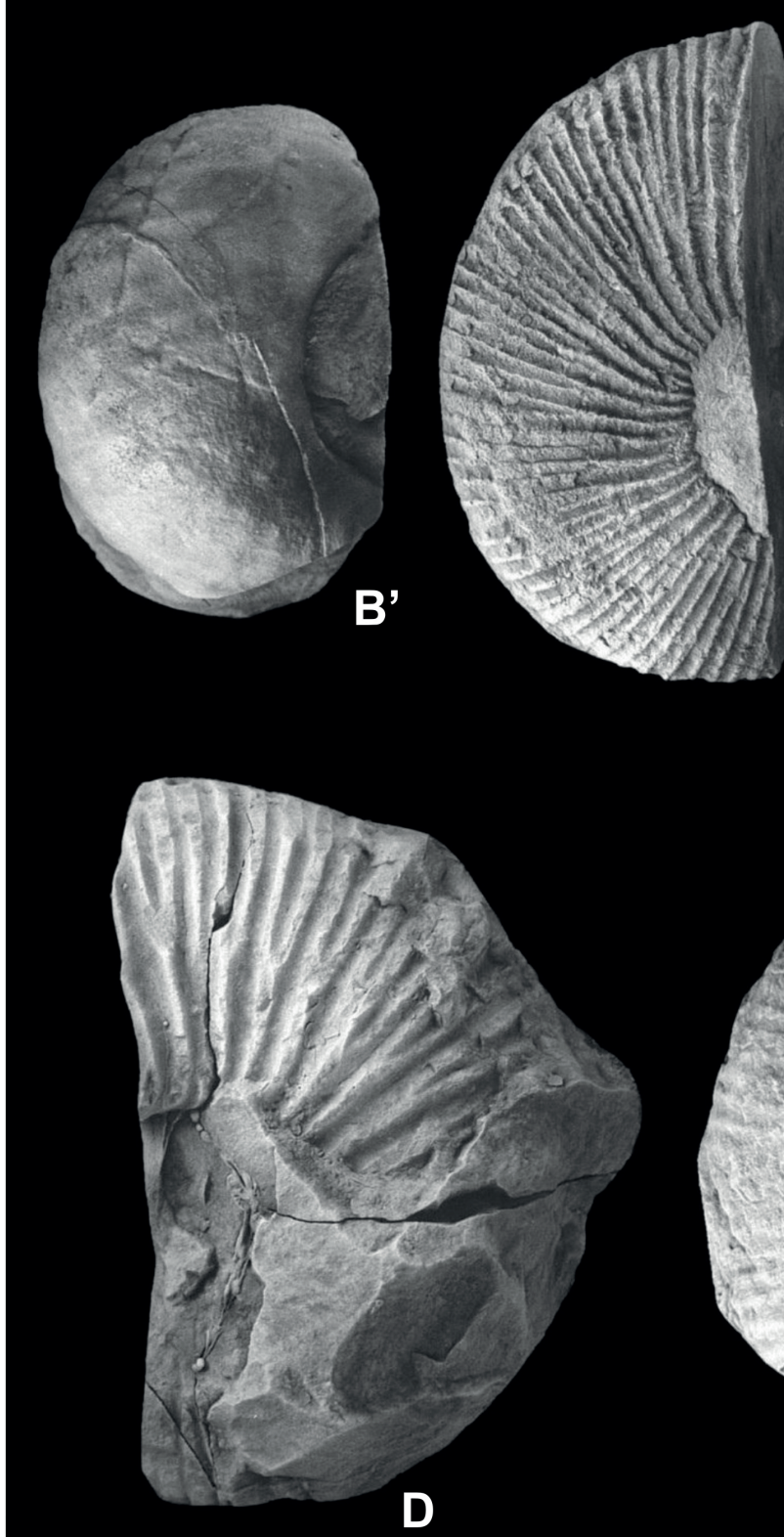

(
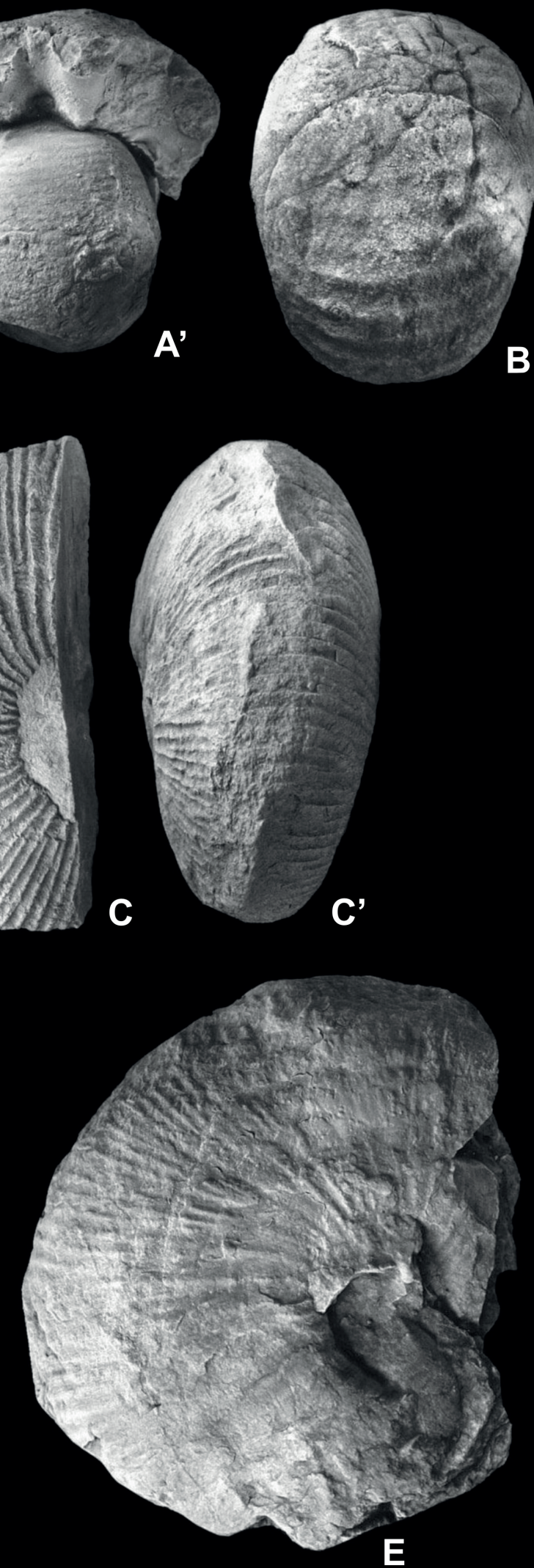

Figure 5. A-A', Kheraiceras cf. bullatum (d'Orbigny) (GZN2011I-S-2b-12) with incomplete phragmocone, Tooy section, Lower Callovian. B-B', Bullatimorphites (Kheraiceras) sp. (GZN2011I-J-3-37) with incomplete phragmocone, Golbini section, Lower Callovian. C-C', Macrocephalites (Macrocephalites) jacquoti (Douvillé) (GZN2011I-S-3-16) with incomplete phragmocone, Tooy section, Bullatus (Macrocephalus) Zone. D, Macrocephalites (Kamptokephalites) cf. kamptus (Buckman) (GZN2011I-S-3-15) with incomplete phragmocone, Tooy section, Lower Callovian. E, Macrocephalites cf. subtrapezinus (Waagen) (GZN2011I-S-3-17) with incomplete phragmocone, Tooy section, Lower Callovian. Dimensions in the text. 
secondaries, which cross the venter. The ribs are strong and dense. Primary and secondary ribs equally coarse. To wards the aperture, whorl height increasing.

Remarks. The specimen can be compared with the holotype of Douvillé (1912), and with the specimens reported by Dietl (1994) and Dietl \& Gygi (1998), and differ from the specimen of Mitta (2009), in having a broader venter.

Stratigraphic distribution. Lower Callovian, Bullatus Zone (Dietl, 1994); the species is recorded for the first time from Iran.

Subgenus Kamptokephalites Buckman, 1922

Macrocephalites (Kamptokephalites) kamptus

(Buckman, 1922)

(Figure 5D)

1922 Kamptokephalites kamptus sp. nov. - Buckman, pl. 347. 1954 Macrocephalites (Kamptokephalites) cf. kamptus Buckman - Jeannet, p. 256, pl. 25, fig. 3.

2012 Macrocephalites (Kamptokephalites) cf. kamptus Buckman - Dietl et al., p. 12, pl. 6, fig. c.

Material. One fragment from Tooy (GZN2011I-S-3-15). Description and remarks. A specimen with incomplete phragmocone, whorl cross-section elliptical. Large-sized, umbilicus narrow, with a vertical wall and a rounded shoulder. Primaries starting at the umbilical margin and dividing near mid-flank into two or three secondaries, terminate at the rounded venter. The ribs are strong, coarse, blunt, distant, and rectiradiate. Primary and secondary ribs equally coarse. To wards the aperture, whorl height increasing.

Remarks. The fragment can be compared with the holotype of Buckman (1922), and differ from the specimen of Dietl et al. (2012), in having stronger ribs. The present specimen is similar to Macrocephalites (Kamptokephalites) lamellosus Thierry (1978, 399, pl. 34, fig. 1) but differs in having strong, distant ribs.

Stratigraphic distribution. Lower Callovian (Jeannet, 1954); the species is recorded for the first time from Iran.

\section{Macrocephalites (Kamptokephalites) cf. subtrapezinus \\ (Waagen, 1875) \\ (Figure 5E)}

1875 Stephanoceras subtrapezinus - Waagen, p. 137, pl. 33, fig. 4.

1978 Macrocephalites subtrapezinus Waagen - Thierry, p. 155, pl. 2, fig. 1, pl. 4, fig. 2.

Material. One fragment from Tooy (GZN2011I-S-3-17). Description. A specimen with incomplete phragmocone, large-sized, umbilicus narrow, with a rounded shoulder, the distant, coarse and prorsiradiate primaries start at the umbilical margin and at around one-third of the height of the flank they divide into two or three dense and prorsiradiate secondaries with some intercalatory ribs. To wards the aperture, whorl height increasing. Secondary ribs denser than primaries but equally moderately coarse.

Remarks. The present fragment resemble the holotype (Waagen, 1875), and differ from the specimen of Thierry (1978) in having finer ribs and whorl height increasing.

Stratigraphic distribution. According to Thierry (1978), Macrocephalites subtrapezinus appears in the lower Callovian; the species is recorded for the first time from Iran.

\section{Dolikephalites Buckman, 1923}

Macrocephalites (Dolikephalites) cf. perseverans Kuhn, 1939

(Figure 6A-A")

cf. 1954 Macrocephalites (Indocephalites) perseverans (Model) - Jeannet, pl. 24, fig. 5, pl. 25, fig. 4.

cf. 1985 Macrocephalites (Dolikephalites) perseverans Kuhn, - Schlegelmilch, pl. 39, fig. 3.

Material. One specimen from Tooy with diameter $57 \mathrm{~mm}$ (GZN2011I-S-3-22).

Dimensions (in mm).

\begin{tabular}{ccccccc}
\hline Specimen & $\mathrm{D}$ & $\mathrm{U} \%$ & $\mathrm{H} \%$ & $\mathrm{~W} \%$ & $\mathrm{PR} / 2$ & $\mathrm{SR} / 2$ \\
\hline $\begin{array}{c}\text { GZN2011I-S-3-22 } \\
\text { (incomplete body } \\
\text { chamber) }\end{array}$ & 57 & 28 & 43 & 78 & 17 & 37 \\
\hline
\end{tabular}

Description. A specimen with incomplete body chamber, shell medium, fat and inflated, with very broad venter and oval whorl cross-section. Involute globular sperocone with moderately narrow umbilicus with rounded shoulder.Venter with rectiradiate, strong, and coarse ribs. Ribbing strong and coarse. The slightly concave and prorsiradiate primaries begin at around mid-flank and divide into two and occasionally three prorsiradiate secondaries, which cross in a slightly convex manner over the venter. Secondary ribs denser than primaries but equally moderately coarse.

Remarks. The specimen can be compared with the holotype of Kuhn $(1939,480$, pl. 3, fig. 7) but differs in being smaller. It differ from the specimen of Jeannet (1954) in having slightly stronger ribs, and differ from the specimen of Schlegelmilch (1985) in having a broader venter.

Stratigraphic distribution. Lower Callovian Kuhn (1939); the species is recorded for the first time from Iran.

Family PACHYCERATIDAE Buckman, 1918

Pachyceras Bayle, 1878

Pachyceras lalandei (d'Orbigny, 1848)

(Figure 4C-C')

1848 Ammonites lalandeanus sp. nov. - d'Orbigny, p. 477, pl. 175, figs. 1-3.

1912 Pachyceras lalandei (d'Orbigny) - Douvillé, p. 44, pl. 8, figs. 1-2. 


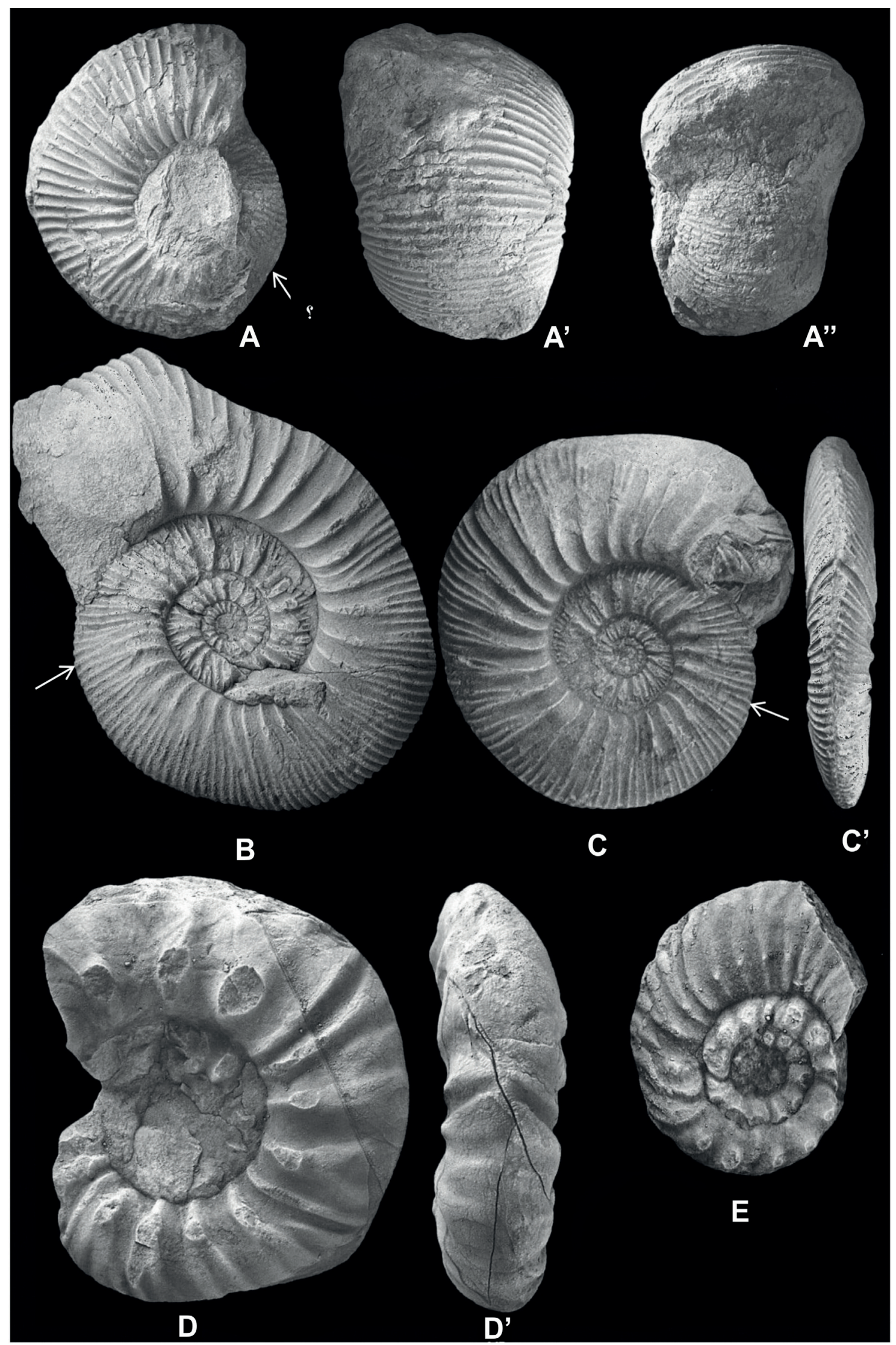

Figure 6. A-A", Macrocephalites (Dolikephalites) cf. perseverans (Kuhn) (GZN2011I-S-3-22) a phragmocone with incomplete body chamber, Tooy section, Lower Callovian. B, C-C', Reineckeia (Tyrannites) sp., Golbini section, middle Callovian; B, specimen GZN2011I-J-3-142. C-C', specimen GZN2011I-J-3-141 with a phragmocone and nearly complete body chamber. D-D', cf. Reineckeia sp. (GZN2011I-J-3-121) with incomplete phragmocone, Golbini section, middle Callovian. E, cf. Reineckeia sp. (GZN2011I-J-3-123) with incomplete phragmocone, Golbini section, middle Callovian. Dimensions in the text. 
Material. One specimen from Golbini with diameter $56 \mathrm{~mm}$ (GZN2011I-J-4-101).

Dimensions (in mm).

\begin{tabular}{ccccccc}
\hline Specimen & $\mathrm{D}$ & $\mathrm{U} \%$ & $\mathrm{H} \%$ & $\mathrm{~W} \%$ & $\mathrm{PR} / 2$ & $\mathrm{SR} / 2$ \\
\hline $\begin{array}{c}\text { GZN2011I-J-4-101 } \\
\text { (incomplete body } \\
\text { chamber) }\end{array}$ & 56 & 12 & 56 & 35 & - & 30 \\
\hline
\end{tabular}

Description. A specimen with incomplete body chamber, shell involute and moderately inflated, venter fairly narrow, umbilicus narrow and deep with steep wall and rounded shoulder. The distinct primaries ribs begin at about onethird of flank height and split into two secondaries halfway or two-thirds up the flank. They cross the venter as strong, coarse, and slightly prorsiradiate ribs. Secondary ribs denser than primaries but equally moderately coarse. Towards the aperture, whorl height increasing.

Remarks. The specimen can be compared with the holotype of d'Orbigny (1848), but differs from the specimen of Douvillé (1912), in being smaller and having slightly weaker primaries. Stratigraphic distribution. According to Douvillé (1912), Pachyceras lalandei occurs in the upper Callovian, Lamberti Zone; the species is recorded for the first time from Iran.

Superfamily PERISPHINCTOIDEA Steinmann, 1890
Family REINECKEIIDAE Hyatt, 1900

Rehmannia Schirardin, 1956

Subgenus Loczyceras Bourquin, 1968

Rehmannia (Loczyceras) segestana (Gemmellaro, 1872) (Figure 8A-A')

1872 Perisphinctes segestana sp. nov. - Gemmellaro, p. 246, pl. 13, figs. 1-3.

1984 Rehmannia (Loczyceras) segestana (Gemmellaro) Cariou, p. 72, pl. 7, figs. 3-4, pl. 8, fig. 1.

Material. Six specimens and two fragments from Golbini (GZN2011I-J-3-126-132a), maximum diameter $59 \mathrm{~mm}$ and generally 51 to $53 \mathrm{~mm}$.

Dimensions (in mm).

\begin{tabular}{cccccccc}
\hline Specimens & $\mathrm{D}$ & $\mathrm{U} \%$ & $\mathrm{H} \%$ & $\mathrm{~W} \%$ & $\mathrm{~N}$ & $\mathrm{PR} / 2$ & $\mathrm{SR} / 2$ \\
\hline $\begin{array}{c}\text { GZN2011I-J-3-126 } \\
\text { (incomplete } \\
\text { phragmocone) }\end{array}$ & 57 & 41 & 37 & 24 & 20 & 15 & 42 \\
$\begin{array}{c}\text { GZN2011I-J-3-131 } \\
\text { (incomplete } \\
\text { phragmocone) }\end{array}$ & 59 & 41 & 36 & 20 & 17 & 12 & 35 \\
$\begin{array}{c}\text { GZN2011I-J-3-130 } \\
\quad \text { incomplete } \\
\text { phragmocone) }\end{array}$ & 51 & 45 & 37 & 25 & 24 & 18 & - \\
$\begin{array}{c}\text { GZN2011I-J-3-127 } \\
\quad \text { incomplete } \\
\text { phragmocone) }\end{array}$ & 53 & 45 & 32 & 23 & 19 & 18 & - \\
$\begin{array}{c}\text { GZN2011I-J-3-129 } \\
\text { (incomplete }\end{array}$ & 53 & 40 & 32 & 26 & 18 & 12 & 34 \\
phragmocone) & & & & & & & \\
\hline
\end{tabular}

Description. Specimens with incomplete phragmocones, shell evolute with nearly ellipsoidal whorl cross-section. Umbilicus shallow, with steep wall, flanks flat, venter fairly narrow. Ribbing relatively coarse and distant. The bullate and radiate primary ribs end at prominent and pyramidal lateral tubercles at one-third of flank height, from where they bifurcate or trifurcate with some intercalatory ribs. The rectiradiate secondary ribs terminate at a ventral furrow. The secondary ribs are fainter and denser than the primaries. Some of the primary ribs do not divide. Primaries on outer whorls bullate. Remarks. The present specimens resemble the holotype (Gemmellaro, 1872), and the material figured by Cariou (1984). However, the holotype exhibits nearly prorsiradiate ribs.

Stratigraphic distribution: middle Callovian (Anceps Zone), Stuebeli Subzone and Bannense horizon (Cariou, 1984); the species is recorded for the first time from Iran.

\section{Rehmannia (Loczyceras) sequanica (Bourquin, 1968)} (Figure 8B-B')

1968 Rehmannia (Loczyceras) sequanica - Bourquin, pl. 24, fig. 3.

1984 Rehmannia (Loczyceras) sequanica nov. subsp. Cariou, p. 172, pl. 24, figs. 4-5.

Material. Six specimens and one fragment from Golbini (GZN2011I-J-3-133-140), maximum diameter $61 \mathrm{~mm}$ and generally 56 to $61 \mathrm{~mm}$.

\section{Dimensions (in mm).}

\begin{tabular}{cccccccc}
\hline Specimens & $\mathrm{D}$ & $\mathrm{U} \%$ & $\mathrm{H} \%$ & $\mathrm{~W} \%$ & $\mathrm{~N}$ & $\mathrm{PR} / 2$ & $\mathrm{SR} / 2$ \\
\hline $\begin{array}{c}\text { GZN2011I-J-3-139 } \\
(\text { incomplete body } \\
\text { chamber) }\end{array}$ & 60 & 43 & 38 & 29 & 19 & 15 & 42 \\
$\begin{array}{c}\text { GZN2011I-J-3-135 } \\
(\text { incomplete body } \\
\text { chamber) }\end{array}$ & 61 & 41 & 38 & 25 & 16 & 13 & 39 \\
$\begin{array}{c}\text { GZN2011I-J-3-134 } \\
(\text { incomplete body } \\
\text { chamber) }\end{array}$ & 57 & 42 & 35 & 23 & 16 & 11 & 36 \\
$\begin{array}{c}\text { GZN2011I-J-3-138 } \\
(\text { incomplete body } \\
\text { chamber) }\end{array}$ & 56 & 41 & 37 & 25 & 19 & 13 & 38 \\
\hline
\end{tabular}

Description. Specimens with incomplete body chambers, shell evolute, flanks flat, venter fairly narrow, whorl crosssection nearly rectangular. Umbilicus shallow, with the steep wall. The bullate and radiate primary ribs end at faint lateral tubercles at around one-third of flank height, from where they bifurcate to quadrifurcate with some intercalatory ribs. The rectiradiate secondary ribs terminate at a ventral furrow. Secondary ribs fainter and denser than the primaries. Some of the primary ribs do not divide. Ribbing denser at the posterior part of the last whorl.

Remarks. Rehmannia (Loczyceras) sequanica is similar to $R$. (Loczyceras) segestana (Gemmellaro), but differs in having fainter and thinner ribs and tubercles and in possessing quadrifurcating secondaries.

Stratigraphic distribution. Middle Callovian (Coronatum 
Zone), Baylei Subzone (Cariou, 1984), the species is recorded for the first time from Iran.

Rehmannia (Loczyceras) cf. hungarica (Till, 1907) (Figure 7A-A")

cf. 1907 Reineckia hungarica sp. nov. - Till, p. 125. cf. 1910 Reineckia hungarica Till - Till, p. 10, pl. 1 (5), fig. 1. 1984 Rehmannia (Loczyceras) cf. hungarica (Till) - Cariou, p. 79 , pl. 8, fig. 9 .

cf. 1986 Rehmannia (Loczyceras) cf. hungarica (Till) Sequeiros et al., p. 78, pl. 1, figs. 4-5.

Material. One specimen with diameter $108 \mathrm{~mm}$ and one fragment from Golbini (GZN2011I-J-3-114-115).

Dimensions (in mm).

\begin{tabular}{cccccccc}
\hline Specimen & $\mathrm{D}$ & $\mathrm{U} \%$ & $\mathrm{H} \%$ & $\mathrm{~W} \%$ & $\mathrm{~N}$ & $\mathrm{PR} / 2$ & $\mathrm{SR} / 2$ \\
\hline $\begin{array}{c}\text { GZN2011I-J-3-114 } \\
\begin{array}{c}\text { incomplete body } \\
\text { chamber) }\end{array}\end{array}$ & 105 & 42 & 34 & 18 & 14 & 9 & 51 \\
\hline
\end{tabular}

Description. An adult specimen with incomplete body chamber, shell large with oval whorl cross-section, flanks flat, venter fairly narrow, umbilicus deep with steep wall. Bullate, distant and prorsiradiate primary ribs ending mostly at conical and sharp tubercles at around one-third of flank height. The slightly prorsiradiate secondaries bifurcate or trifurcate with some intercalatory ribs, ending at a smooth ventral band. Some of the primary ribs do not divide; they are also more distant than the secondaries. On the outer part of the last whorl the ribs are irregular. Ribbing denser at the posterior part of the last whorl.

Remarks. The specimens is similar to the material studied by Cariou (1984), but differ from specimens described by Sequeiros et al. (1986) in having distant ribs and and whorl height increasing.

Stratigraphic distribution. Middle Callovian Anceps Zone (Cariou, 1984), the species is recorded for the first time from Iran.

\section{Rehmannia (Loczyceras) intermedia (Bourquin 1968)} (Figure 8C-C')

1968 Reineckia intermedia nov. sp. - Bourquin, p. 100, pl. 23, fig. 6, pl. 2, fig. 12, pl. 22, fig. 10.

1984 Rehmannia (Loczyceras) intermedia (Bourquin) Cariou, p. 144, pl. 19, figs. 1-4.

Material. One specimen with diameter $62 \mathrm{~mm}$ and two fragments from Golbini (GZN2011I-J-3-116-118).

Dimensions (in mm).

\begin{tabular}{cccccccc}
\hline Specimen & $\mathrm{D}$ & $\mathrm{U} \%$ & $\mathrm{H} \%$ & $\mathrm{~W} \%$ & $\mathrm{~N}$ & $\mathrm{PR} / 2$ & $\mathrm{SR} / 2$ \\
\hline $\begin{array}{c}\text { GZN2011I-J-3-116 } \\
\text { (incomplete body } \\
\text { chamber) }\end{array}$ & 60 & 39 & 37 & 27 & 14 & 10 & 41 \\
\hline
\end{tabular}

Description. A specimen with incomplete body chamber, flanks flat, whorl cross-section broad-ovate to rectangular, umbilicus shallow with the steep wall. The bullate, distant and prorsiradiate primary ribs end mostly at pyramidal and sharp tubercles at around one-third of flank height. The prorsiradiate secondaries are trifurcate, quadrifurcate, seldom quinquefurcate, ending at a ventral furrow. There are also some single intercalatory ribs. The secondary ribs are denser than the primary ones. Ribbing denser at the posterior part of the last whorl.

Remarks. The present specimen differ from the holotype with respect to their bullate ribs and sharp tubercles.

Stratigraphic distribution: Middle Callovian Anceps Zone (Cariou, 1984); the species is recorded for the first time from Iran.

\section{Reineckeia (Reineckeia) Bayle, 1878}

Subgenus Tyrannites Cariou, 1984

Reineckeia (Tyrannites) sp.

(Figures 6B, C-C')

Material. Two specimens and five fragments from Golbini (GZN2011I-J-3-142-141), the first (J-3-141) is small ( $\mathrm{D}=72$ $\mathrm{mm})$; the second $(\mathrm{J}-3-142)$ is larger $(\mathrm{D}=92 \mathrm{~mm})$.

\section{Dimensions (in mm).}

\begin{tabular}{cccccccc}
\hline Specimens & $\mathrm{D}$ & $\mathrm{U} \%$ & $\mathrm{H} \%$ & $\mathrm{~W} \%$ & $\mathrm{~N}$ & $\mathrm{PR} / 2$ & $\mathrm{SR} / 2$ \\
\hline $\begin{array}{c}\text { GZN2011I-J-3-142 } \\
\text { (nearly complete } \\
\text { body chamber) }\end{array}$ & 92 & 40 & 36 & 27 & 19 & 14 & 45 \\
$\begin{array}{c}\text { GZN2011I-J-3-141 } \\
\text { (nearly complete } \\
\text { body chamber) }\end{array}$ & 72 & 40 & 35 & 18 & 16 & 15 & 51 \\
\hline
\end{tabular}

Description. Adult specimens with nearly complete body chambers, flanks flat, venter fairly narrow, umbilicus shallow with the steep wall. Ribbing relatively coarse, strong and distant. Primary ribs on the inner flank slightly bullate, terminating at around one-third of flank height in small and weak tubercles. From there they bifurcate to quadrifurcate in a prorsiradiate fashion (specimen J-5-142) or bifurcate or trifurcate in a prorsiradiate fashion (specimen J-5-141). Secondaries with intercalatory ribs and ending at the ventral furrow. Secondaries denser and finer than primaries. Ribbing on outer whorls stronger, coarser, and more distant than on inner whorls. Towards the aperture primaries are strong and distant and whorl height increasing.

Remarks. The specimens differ from Reineckeia (Tyrannites) convex (Cariou, 1984) in having stronger, blunter and more rectiradiate ribs.

Stratigraphic distribution. The present specimens come from the middle Callovian (Cariou, 1984), and the taxon is for the first time from Iran.

\section{Reineckeia (Tyrannites) convex Cariou, 1984} (Figure 7B-B')

1984 Reineckeia (Tyrannites) convex sp. nov. - Cariou, p. 197, pl. 28, figs. 3-4, pl. 29, figs. 1-4. 


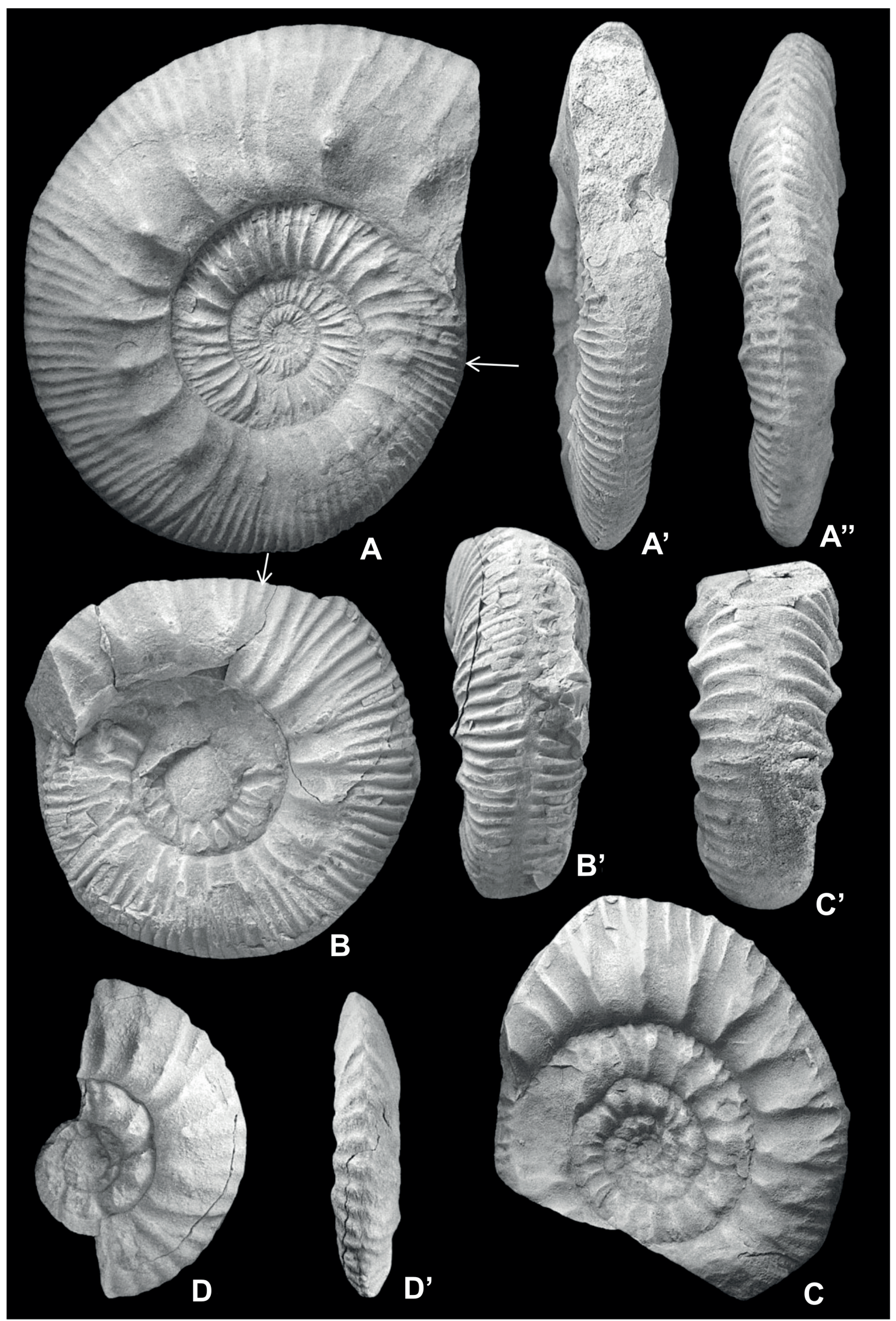

Figure 7. A-A", Rehmannia (Loczyceras) cf. hungarica (Till) (GZN2011I-J-3-114), a phragmocone with incomplete body chamber, Golbini section, Anceps Zone. B-B', Reineckeia (Tyrannites) convex (Cariou) (GZN2011I-J-3-119), a phragmocone with incomplete body chamber, Golbini section, Gracilis Zone. C-C', Reineckeia (Reineckeia) cf. fehlmanni (Jeannet) (GZN2011I-J-3-108) with incomplete phragmocone, Golbini section, Middle Callovian. D-D', Reineckeia sp. (GZN2011I-J-3-149) with incomplete phragmocone, Golbini section, Callovian. Dimensions in the text. 


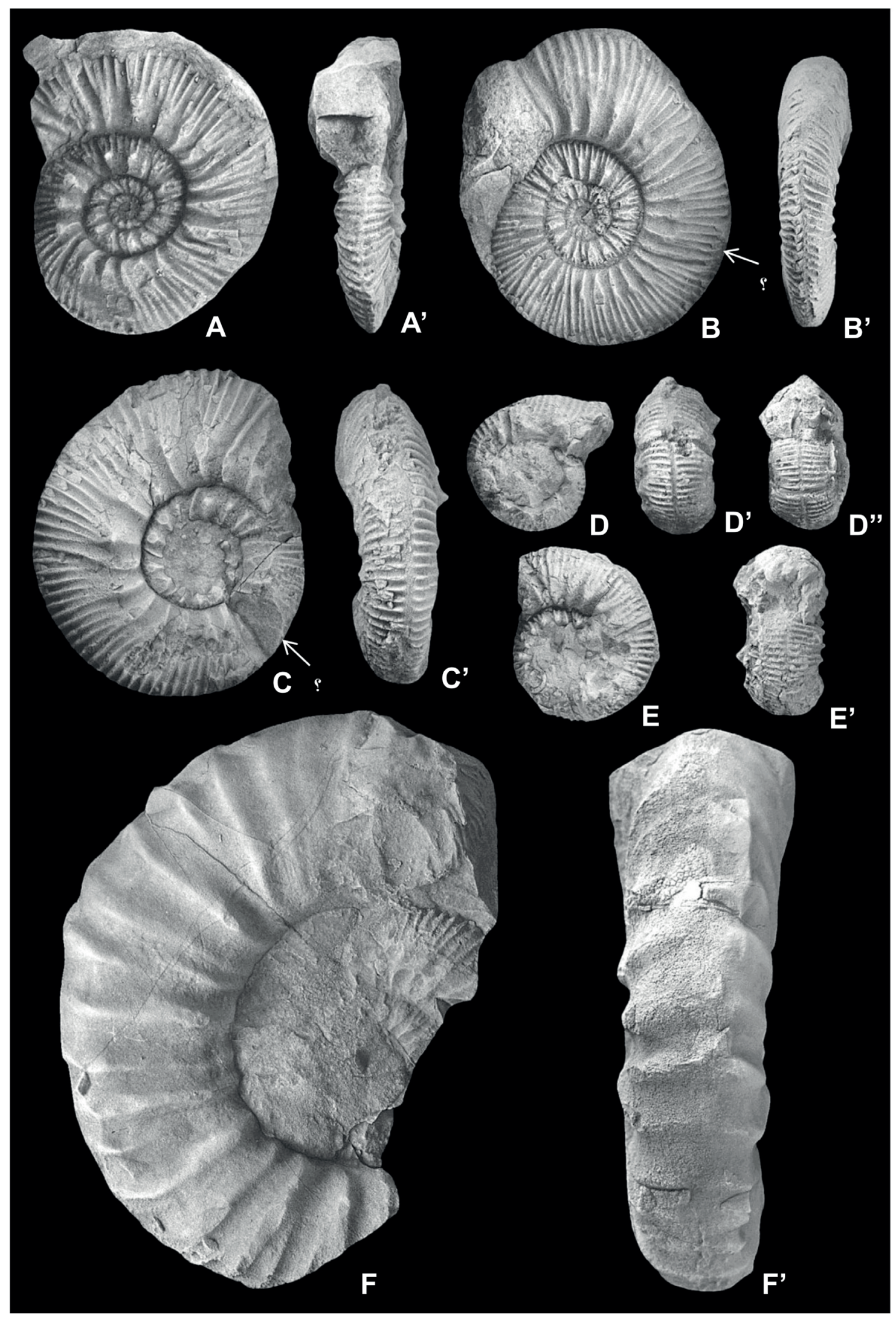

Figure 8. A-A', Rehmannia (Loczyceras) segestana (Gemmellaro) (GZN2011I-J-3-126) with incomplete phragmocone, Golbini section, Anceps Zone. B-B', Rehmannia (Loczyceras) sequanica (Cariou) (GZN2011I-J-3-135), a phragmocone with incomplete body chamber, Golbini section, Coronatum Zone. C-C', Rehmannia (Loczyceras) intermedia (Bourquin) (GZN2011I-J-3-116), a phragmocone with incomplete body chamber, Golbini section, Anceps Zone. D-D", Reineckeia (Reineckeia) nodosa (Till) (GZN2011I-S-3-120) with incomplete phragmocone, Tooy section, Athleta Zone. E-E', Reineckeia (Reineckeia) aff. Polycosta (Kuhn) (GZN2011I-S-3-127) with incomplete phragmocone, Tooy section, Anceps Zone. F-F', cf. Reineckeia sp. (GZN2011I-J-3-120) with incomplete phragmocone, Golbini section, middle Callovian. Dimensions in the text. 
Material. One specimen from Golbini with diameter $78 \mathrm{~mm}$ (GZN2011I-J-3-119).

Dimensions (in mm).

\begin{tabular}{cccccccc}
\hline Specimen & $\mathrm{D}$ & $\mathrm{U} \%$ & $\mathrm{H} \%$ & $\mathrm{~W} \%$ & $\mathrm{~N}$ & $\mathrm{PR} / 2$ & $\mathrm{SR} / 2$ \\
\hline $\begin{array}{c}\text { GZN2011I-J-3-119 } \\
\text { (incomplete body } \\
\text { chamber) }\end{array}$ & 78 & 38 & 35 & 32 & 15 & 11 & 37 \\
\hline
\end{tabular}

Description. A specimen with incomplete body chamber, umbilicus is deep with steep umbilical wall and rectangular whorl cross-section and venter rounded to broad. The bullate and distant primary ribs end mostly at conical and sharp tubercles at around one-third of flank height. The rectiradiate secondaries are bifurcating or trifurcating with single intercalatory ribs, all ending at a ventral furrow. The secondary ribs are denser than the primaries. Rarely, primary ribs do not divide.

Remarks. The blunt, coarse and strong ribs distinguish this species from other species.

Stratigraphic distribution. Lower Callovian Gracilis Zone, Pictava Subzone and horizon (Cariou, 1984), the species is recorded for the first time from Iran.

Subgenus Reineckeia Bayle, 1878

\section{Reineckeia (Reineckeia) cf. fehlmanni Jeannet, 1951 (Figure 7C-C')}

cf. 1951 Reineckeia fehlmanni sp. nov. - Jeannet, p. 134, pl. 53, figs. 316-317.

cf. 1984 Reineckeia (Reineckeia) fehlmanni Jeannet - Cariou, p. 278, pl. 42, figs. 1-3.

cf. 1986 Reineckeia (Reineckeia) fehlmanni Jeannet Sequeiros et al., p. 79, pl. 2, fig. 3.

Material. Three fragments from Golbini (GZN2011I-J-3-108-113).

Description. Specimens with incomplete phragmocones, whorl cross-section rectangular, venter broad, and umbilicus shallow, low with steep wall. Nearly the entire bullate and distant primary ribs end at pyramidal, sharp tubercles at around one-third of flank height. Bullate secondaries bifurcate or trifurcate with single intercalatory ribs, ending at a smooth ventral band. Ribs on the inner part in the last visible whorl rectiradiate and on the outer part prorsiradiate.

Remarks. The fragments described here differ from the holotype with respect to their bullate and long ribs and sharp, big tubercles. Moreover, the ribs are first rectiradiate and then prorsiradiate, while in the specimens described by Cariou (1984, pl. 42), and Jeannet (1951, pl. 53) the ribs are usually rectiradiate. The specimen differ from the reported by Sequeiros et al. (1986) in having long ribs, fainter, smaller tubercles and whorl height increasing.

Stratigraphic distribution. Middle Callovian (Cariou, 1984); the species is recorded for the first time from Iran.

Reineckeia (Reineckeia) anceps (Reinecke, 1818) (Figures 4F-F', G)
1818 Nautilus anceps - Reinecke, p. 82, pl. 7, fig. 61.

1939 Reineckeia anceps Reinecke - Kuhn, p. 491, pl. 2, fig. 2. 1951 Reineckeia anceps Reinecke - Jeannet, p. 127, pl. 48, figs. 2-3.

1984 Reineckeia (Reineckia) anceps (Reinecke) - Cariou, p. 220, pl. 33, figs. 4-5, pl. 34, figs. 1-2, 5, pl. 35, figs. 1, 4-5. 1988 Reineckeia (Reineckeia) anceps (Reinecke) - Cariou \& Krishna, p. 160, pl. 2, figs. 2-3, pl. 3, fig. 1.

1995 Reineckeia (Reineckeia) sp. ex gr. $R(R$.$) anceps$ (Reinecke) - Seyed-Emami et al., p. 43, pl. 2, fig. 1.

2002 Reineckeia (Reineckeia) anceps (Reinecke) - SeyedEmami et al., p. 185, figs. 2-4.

Material. One specimen and one fragment from Golbini (GZN2011I-J-3-106-107) and one specimens and three fragments from Tooy (GZN2011I-S-3-122a-f), the first (J$3-106)$ is small $(\mathrm{D}=27 \mathrm{~mm})$; the second $(\mathrm{S}-3-122)$ is larger (D $=37 \mathrm{~mm})$.

Dimensions (in mm).

\begin{tabular}{cccccccc}
\hline Specimens & $\mathrm{D}$ & $\mathrm{U} \%$ & $\mathrm{H} \%$ & $\mathrm{~W} \%$ & $\mathrm{~N}$ & $\mathrm{PR} / 2$ & $\mathrm{SR} / 2$ \\
\hline $\begin{array}{c}\text { GZN2011I-S-3-122 } \\
\text { (incomplete } \\
\text { phragmocone) }\end{array}$ & 37 & 34 & 47 & 47 & 19 & 12 & 31 \\
$\begin{array}{c}\text { GZN2011I-J-3-106 } \\
\text { (incomplete body } \\
\text { chamber) }\end{array}$ & 27 & 44 & 33 & 48 & 18 & 12 & 30 \\
\hline
\end{tabular}

Description. A specimen with incomplete body chamber (J-3-106), and a specimen with incomplete phragmocone ( $\mathrm{J}$ 3-122), moderately evolute, coronate Reineckeia with broadoval to broad-rectangular whorl cross-section. Umbilicus shallow, low umbilical wall near-vertical with a distinct rounded shoulder. Ribbing relatively coarse. Slightly bullate and somewhat prorsiradiate primary ribs end at prominent and pyramidal lateral tubercles at one-third of the flank height, from where they trifurcate in a somewhat prorsiradiate manner. Seldom they quadrifurcate with some intercalatory ribs. The slightly incurved secondary ribs terminate at a smooth ventral band. Four prorsiradiate constrictions per whorl.

Remarks. With respect to the prominent conical tubercles and rather strict trifurcate secondaries, our specimens match well the inner whorls of Reineckeia (Reineckeia) anceps as figured by Cariou (1984, pl. 34, fig. 5; 1994, pl. 61, figs. 1-3), Jeannet (1951, pl. 48, figs. 2-3), and Kuhn (1939, pl. 2, figs. 2, 11, 15).

Stratigraphic distribution. Middle Callovian Anceps Zone (Cariou, 1984).

\section{Reineckeia (Reineckeia) aff. polycosta Kuhn, 1939 (Figure 8E-E')}

aff. 1939 Reineckeia polycosta sp. nov. - Kuhn, p. 483, pl. II, fig. 24.

aff. 1984 Reineckeia (Reineckeia) cf. polycosta Kuhn Cariou, p. 281, pl. 42, fig. 4.

Material. One specimen from Tooy with diameter $33 \mathrm{~mm}$ (GZN2011I-S-3-127). 
Dimensions (in mm).

\begin{tabular}{ccccccc}
\hline Specimen & $\mathrm{D}$ & $\mathrm{U} \%$ & $\mathrm{H} \%$ & $\mathrm{~W} \%$ & $\mathrm{PR} / 2$ & $\mathrm{SR} / 2$ \\
\hline $\begin{array}{c}\text { GZN2011I-S-3-127 } \\
\text { (incomplete } \\
\text { phragmocone) }\end{array}$ & 33 & 42 & 36 & 42 & - & 34 \\
\hline
\end{tabular}

Description. A specimen with incomplete phragmocone, venter rounded and broad, broad-oval whorl cross-section, umbilicus shallow with a vertical wall. Bullate rectiradiate primary ribs ending at prominent, conical, and sharp lateral tubercles near the umbilical margin, from where they form trifurcate, seldom quadrifurcate and quinquefurcate bundles. Rectiradiate secondary ribs terminating at a ventral furrow. Four deep, prorsiradiate constrictions on the last visible whorl. Remarks. The present specimen closely resembles the holotype figured by Kuhn (1939, pl. 2, fig. 24) but differ in the secondaries being rectiradiate, whereas in the holotype they are prorsiradiate. The specimen differ from the Cariou (1984) one in having sharper tubercles.

Stratigraphic distribution. Middle Callovian Anceps Zone (Cariou, 1984); the species is recorded for the first time from Iran.

\section{Reineckeia (Reineckeia) nodosa Till, 1907}

(Figure 8D-D”)

1907 Reineckeia nodosa n. sp. - Till, p. 124.

1939 Reineckeia nodosa Till - Kuhn, p. 34, pl. II, fig. 14.

1975 Reineckeia (Reineckeia) nodosa Till - Hillebrandt \& Gröschke, pl. 6, fig. 13

1984 Reineckeia (Reineckeia) nodosa Till - Cariou, p. 246, pl. 37, figs. 5-6.

2013 Reineckeia (Reineckeia) nodosa Till - Seyed-Emami et al., p. 55, 8k-1.

Material. Two specimens from Tooy with diameter $27 \mathrm{~mm}$ (GZN2011I-S-3-120-121).

Dimensions (in mm).

\begin{tabular}{lccccccc}
\hline Specimens & $\mathrm{D}$ & $\mathrm{U} \%$ & $\mathrm{H} \%$ & $\mathrm{~W} \%$ & $\mathrm{~N}$ & $\mathrm{PR} / 2$ & $\mathrm{SR} / 2$ \\
\hline $\begin{array}{c}\text { GZN2011I-S-3-120 } \\
\text { (incomplete } \\
\text { phragmocone) }\end{array}$ & 27 & 44 & 33 & 55 & 11 & 6 & 25 \\
\hline $\begin{array}{c}\text { GZN2011I-S-3-121 } \\
\text { (incomplete } \\
\text { phragmocone) }\end{array}$ & 27 & 48 & 30 & 44 & 11 & 6 & - \\
\hline
\end{tabular}

Description. Specimens with incomplete phragmocones, whorl cross-section oval, venter rounded and broad. Bullate, distant and prorsiradiate primary ribs ending at prominent and sharp tubercles at around mid-flank, from where they usually form quadrifurcate bundles. Prorsiradiate secondary ribs terminating at a ventral furrow. Three deep, prorsiradiate constrictions on the last visible whorl. Secondary ribs finer and denser than primaries.

Remarks. The present specimens resemble the holotype (Kuhn, 1939, pl. 2, fig. 14), and the material figured by Cariou (1984, pl. 37, figs. 5-6). However, the holotype exhibits nearly prorsiradiate ribs. Reineckeia nodosa differs from $R$. (Reineckia) anceps by its strong and coarse tubercles.
Stratigraphic distribution. Upper Callovian Athleta Zone, Collotiformis Subzone (Hillebrandt \& Gröschke, 1975). Reineckeia nodosa ranges according to Cariou (1984) from late middle Callovian (upper Coronatum Zone) to early upper Callovian (Collotiformis Subzone).

$$
\text { cf. Reineckeia sp. }
$$

(Figures 6D-D', E; 8F-F')

Material. Three incomplete specimens (GZN2011I-J-3-120, 121,123 ), specimen J-3-120 with incomplete phragmocone and body chamber, specimens J-3-121, 123 with incomplete phragmocones.

Description. The specimens are the fragment of a large quadrate phragmocone, shell large, with a rectangular-oval whorl cross-section and a broad venter. Umbilicus shallow, with a steep wall. Ribbing coarse and very strong. Rectiradiate, bullate, distant and somewhat prorsiradiate primary ribs ending at prominent and pyramidal lateral tubercles at onethird of the flank height. From there the bullate secondaries bifurcate with single intercalatory ribs, crossing somewhat prorsiradiate over the venter. Prorsiradiate constrictions on the last visible whorl. Secondary ribs denser than primaries but equally moderately coarse. Towards the aperture, primaries distant and whorl height increasing. Ribbing on the last visible whorl (large specimen GZN2011I-J-3-120 is nearly fully grown) stronger and more distant than on earlier whorls (e.g. Figure $\left.8 \mathrm{~F}-\mathrm{F}^{\prime}\right)$.

Stratigraphic distribution. The present specimens come from the lower Callovian.

Family PERISPHINCTIDAE Steinmann, 1890 Subfamily PROPLANULITINAE Buckman, 1921

\author{
Hubertoceras Spath, 1930 \\ cf. Hubertoceras sp. \\ (Figure 9A)
}

Material. One specimen from Tooy (GZN2011I-S-3-110). Description. A specimen with incomplete body chamber, flanks flat, venter fairly narrow, whorl cross-section rounded, umbilicus shallow with vertical wall. Primaries strong and rectiradiate, dividing into two secondaries (some of the ribs do not divide) near mid-flank and crossing the venter. Ribbing denser at the posterior part of the last whorl. Ribs on inner whorls finer and denser than those on outer whorls. Primary and secondary ribs equally coarse.

Stratigraphic distribution. Hubertoceras has been recorded from the middle Callovian (Spath, 1930).

\section{Subfamily PSEUDOPERISPHINCTINAE Schindewolf,} 1925

Loboplanulites Buckman, 1925

Loboplanulites cf. L. collociaris (Quenstedt, 1887)

(Figure 9E-E') 
cf. 1887 Ammonites triplicatus colliciaris sp. nov. - Quenstedt, p. 680 , pl. 80 , fig. 1 .

Material. One fragment from Tooy (GZN2011I-S-3-54), [m]. Description. A crushed microconch specimen with incomplete phragmocone, shell moderately inflated, whorl cross-section nearly subrounded, umbilicus shallow. Strong, blunt primaries dividing at around two-thirds of the flank height into two slightly rursiradiate secondaries (some of the ribs do not divide) and crossing the venter. Primary and secondary ribs are equally coarse.

Remarks. The fragment described here differ from the holotype with respect to their slightly strong bullate ribs.

Stratigraphic distribution. The present fragment comes from the lower Callovian; the species is recorded for the first time from Iran.

\section{Choffatia Siemiradzki, 1898}

Subgenus Choffatia Siemiradzki, 1898

Choffatia (Choffatia) sakuntala Spath, 1931

(Figures 4H, 9F)

1931 Choffatia (Choffatia) sakuntala sp. nov. - Spath, p. 351, pl. 48, fig. 4.

1970b Choffatia (Choffatia) sakuntala Spath - Mangold, p. 152, pl. 12, fig. 1, pl. 13, fig. 3 .

Material. Two fragments from Tooy (GZN2011I-S-3-50-51), [M].

Description. Crushed specimens with incomplete phragmocones and body chambers, macrooconchs, whorl cross-section ovate, venter broad, umbilicus moderately wide and deep, umbilical wall vertical. Ribbing on outer whorls stronger, coarser, and more distant than on inner whorls. Strong, coarse, distant primaries dividing at around three-fourth of flank height into two or three secondaries which, together with some intercalated ribs, cross the venter. Secondaries denser and fainter than the primaries. Towards the aperture, primaries distant and whorl height increasing.

Remarks. The fragments resemble the holotype (Spath, 1931, pl. 48, fig. 4), and the material figured by Mangold (1970b, pl. 13, fig. 3). The present specimens are considered to be macroconchs.

Stratigraphic distribution. Lower Callovian Gracilis Zone (Mangold, 1970b); the species is recorded for the first time from Iran.

\section{Choffatia kontkiewiczi (Siemiradzki, 1894) (Figures 4I-I'; 9B, C-C', D-D')}

1894 Perisphinctes kontkiewiczi sp. nov. - Siemiradzki, p. 513, pl. 38, figs. 3-4.

1931 Grossouvria aff. kontkiewiczi (Siemiradzki) - Spath, p. 368, pl. 60, fig. 2, pl. 63, fig. 7.

1985 Choffatia (Grossouvria) kontkiewiczi (Siemiradzki) Schlegelmilch, p. 130, pl. 49, fig. 10.
2009 Choffatia (Grossouvria) ex. gr. kontkiewiczi Siemiradzki - Schlögl et al., p. 69, fig. 7(11).

Material. 22 specimens and five fragments from Golbini (GZN2011I-J-3-194-200, 204-208, 210, 233), maximum diameter $79 \mathrm{~mm}$ and minimum $21 \mathrm{~mm}$, generally 30 to $39 \mathrm{~mm}$. Dimensions (in mm).

\begin{tabular}{ccccccc}
\hline Specimens & $\mathrm{D}$ & $\mathrm{U} \%$ & $\mathrm{H} \%$ & $\mathrm{~W} \%$ & $\mathrm{PR} / 2$ & $\mathrm{SR} / 2$ \\
\hline $\begin{array}{c}\text { GZN2011I-J-3-210 } \\
\text { (macroconchs, } \\
\text { incomplete body } \\
\text { chamber) }\end{array}$ & 79 & 43 & 33 & 20 & 13 & - \\
$\begin{array}{c}\text { GZN2011I-J-3-195 } \\
\text { (microconchs, } \\
\text { incomplete body } \\
\text { chamber) }\end{array}$ & 36 & 45 & 34 & 17 & 15 & - \\
$\begin{array}{c}\text { GZN2011I-J-3-194 } \\
\text { (microconchs, } \\
\text { incomplete } \\
\text { phragmocone) }\end{array}$ & 38 & 49 & 35 & 22 & 18 & 41 \\
$\begin{array}{c}\text { GZN2011I-J-3-208 } \\
\text { (microconchs, }\end{array}$ & 33 & 47 & 34 & 21 & 16 & - \\
incomplete body \\
chamber) \\
$\begin{array}{c}\text { GZN2011I-J-3-196 } \\
\text { (microconchs, }\end{array}$ & 30 & 47 & 30 & 27 & 17 & - \\
incomplete body \\
chamber) \\
$\begin{array}{c}\text { GZN2011I-J-3-197 } \\
\text { (incomplete } \\
\text { phragmocone) }\end{array}$ & 23 & 43 & 35 & 30 & 16 & - \\
$\begin{array}{c}\text { GZN2011I-J-3-199 } \\
\text { (incomplete } \\
\text { phragmocone) }\end{array}$ & 21 & 48 & 29 & 27 & 18 & - \\
$\begin{array}{c}\text { GZN2011I-J-3-198 } \\
\text { (incomplete } \\
\text { phragmocone) }\end{array}$ & 21 & 48 & 33 & 29 & 18 & - \\
$\begin{array}{c}\text { GZN2011I-J-3-200 } \\
\text { (incomplete } \\
\text { phragmocone) }\end{array}$ & 15 & 49 & 35 & 33 & 15 & - \\
\hline & & & & & & \\
\hline
\end{tabular}

Description. Macroconchs (J-3-210), including with incomplete body chamber and specimens (J-3-194-195, 208) microconchs with incomplete body chambers and other specimens (J-3-197-199, 200) with incomplete phragmocones, whorl cross-section subrounded, umbilicus shallow, umbilical wall nearly vertical. Blunt, strong, and slightly parabolic primaries dividing mainly at around three-fourth of the flank height into two or three secondaries which, together with some intercalated ribs, cross rursiradiate over the venter. Some of the primary ribs have a common origin close to the umbilical margin. Ribbing on inner whorls denser and more prorsiradiate than on outer whorls. Towards the aperture, primaries distant and whorl height increasing.

Remarks. Mangold (1970b, p.175) distinguished this species from others by its distinctly parabolic ribs. Morphological characters place these specimens between $C$. (G.) kontkiewiczi kontkiewiczi Siemiradzki (1894), C. (G.) kontkiewiczi composita Pfaehler-Erath (1938) and C. (G.) kontkiewiczi incomposita Pfaehler-Erath (1938).

Stratigraphic distribution. Upper part of the middle Callovian Coronatum Zone, Obductum Subzone (Mangold, 1970b); the species isrecorded for the first time from Iran. 
Grossouvria Siemiradzki, 1898

Grossouvria sp.

(Figure 10A-A')

Material. One specimen from Tooy with diameter $33 \mathrm{~mm}$ (GZN2011I-S-3-53).

Dimensions (in mm).

\begin{tabular}{ccccccc}
\hline Specimen & $\mathrm{D}$ & $\mathrm{U} \%$ & $\mathrm{H} \%$ & $\mathrm{~W} \%$ & $\mathrm{PR} / 2$ & $\mathrm{SR} / 2$ \\
\hline $\begin{array}{c}\text { GZN2011I-S-3-53 } \\
\begin{array}{c}\text { (incomplete } \\
\text { phragmocone) }\end{array}\end{array}$ & 33 & 42 & 35 & 33 & 23 & 46 \\
\hline
\end{tabular}

Description and remarks. A specimen with incomplete phragmocone, whorl cross-section rounded, umbilicus shallow with vertical wall, venter broad. Primaries dense and slightly prorsiradiate, starting at the umbilical margin, dividing into two secondaries near mid-flank, and crossing the venter. Primary and secondary ribs equally coarse, but the ribs on the inner whorls denser than those on the outer whorls. Three prorsiradiate and fairly deep constrictions on the last visible whorl.

Stratigraphic distribution. The present specimens come from the middle Callovian.

Binatisphinctes Buckman, 1921

Subgenus Okaites Sasonov, 1961

Binatisphinctes (Okaites) cf. mosquensis (Fischer, 1843) (Figure 10H)

cf. 1843 Ammonites mosquensis nov. sp. - Fischer, p. 110, pl. 3, figs. 4-7.

cf. 1898 Perisphinctes mosquesis Fischer - Siemiradzki, p. 104, pl. 21, fig. 13.

cf. 1970b Binatisphinctes (Okaites) cf. mosquensis (Fischer in Siemiradzki) - Mangold, p. 204, pl. 10, fig. 4.

cf. 1987 Binatisphinctes (Okaites) mosquensis Fischer Meledina, p. 74, pl. 20, fig. 6, pl. 22, fig. 3, pl. 23, fig. 2.

Material. Two fragments from Golbini (GZN2011I-J-3-232, $225)$, the first $(\mathrm{J}-3-225)$ is small $(\mathrm{D}=49 \mathrm{~mm})$; the second $(\mathrm{J}-3-232)$ is larger $(\mathrm{D}=57 \mathrm{~mm})$.

Dimensions (in mm).

\begin{tabular}{ccccccc}
\hline Specimens & $\mathrm{D}$ & $\mathrm{U} \%$ & $\mathrm{H} \%$ & $\mathrm{~W} \%$ & $\mathrm{PR} / 2$ & $\mathrm{SR} / 2$ \\
\hline $\begin{array}{c}\text { GZN2011I-J-3-232 } \\
\text { (incomplete } \\
\text { phragmocone) }\end{array}$ & 57 & 49 & 33 & 18 & 17 & - \\
$\begin{array}{c}\text { GZN2011I-J-3-225 } \\
\text { (incomplete } \\
\text { phragmocone) }\end{array}$ & 49 & 45 & 35 & 20 & 16 & - \\
\hline
\end{tabular}

Description. Specimens with incomplete phragmocones, whorl cross-section oval, umbilicus shallow with steep wall. Ribs irregular. Coarse, fine and rectiradiate primaries starting at the umbilical margin, dividing mainly into two rursiradiate ribs at around two-thirds of flank height, and crossing the venter. Some of the ribs do not divide. Secondary ribs finer and denser than primaries. Ribbing on the last visible whorl increasingly distant.

Remarks. The present material is similar to the specimens described by Siemiradzki (1898, p. 104) and Meledina (1987, p. 74) but differs in having a narrow venter and in being of large size. The specimens can also be compared with Mangold (1970b) material.

Stratigraphic distribution. Upper part of the middle Callovian, Coronatum Zone and Obductum Subzone (Mangold, 1970b); the species is recorded for the first time from Iran.

$$
\text { Indosphinctes Spath, } 1930
$$

Subgenus Elatmites Shevyrev, 1960

Indosphinctes (Elatmites) cf. revili Mangold, 1970

(Figure 10C)

cf. 1970b Indosphinctes (Elatmites) revili sp. nov. - Mangold, p. 111, pl. 7, fig. 2 .

cf. 1985 Indosphinctes (Elatmites) revili Mangold Schlegelmilch, p. 126, pl. 48, fig. 1.

Material. One fragment from Golbini with diameter $79 \mathrm{~mm}$ (GZN2011I-J-3-224).

Dimensions (in mm).

\begin{tabular}{ccccccc}
\hline Specimen & $\mathrm{D}$ & $\mathrm{U} \%$ & $\mathrm{H} \%$ & $\mathrm{~W} \%$ & $\mathrm{PR} / 2$ & $\mathrm{SR} / 2$ \\
\hline $\begin{array}{c}\text { GZN2011I-J-3-224 } \\
\text { (incomplete body } \\
\text { chamber) }\end{array}$ & 64 & 43 & 33 & 15 & 12 & 70 \\
\hline
\end{tabular}

Description. A specimen with incomplete body chamber, whorl cross-section high-ovate, flanks flat, venter fairly narrow, umbilicus shallow with the steep wall. Ribbing on inner whorls denser and more regular than on outer whorls. Primaries strong, coarse, distant and bullate up to about midflank but gradually fainting and splitting at around two-thirds of flank height into fine and dense secondaries which, together with some intercalated ribs, continue across the venter. One constriction is seen on the last visible whorl.

Remarks. The present fragment resembles the holotype of Mangold (1970b, pl. 7, fig. 2) but differs in being smaller and having slightly weaker primaries.

Stratigraphic distribution. Lower Callovian Gracilis Zone (Mangold, 1970b); the species is recorded for the first time from Iran.

\section{Indosphinctes (Elatmites) sp.} (Figure 10B-B')

Material. One fragment from Golbini (GZN2011I-J-209).

Description. A crushed specimen with incomplete body chamber, flanks flat, venter narrow, umbilical wall steep. Ribbing denser and slightly prorsiradiate on inner whorls and irregular. Primaries distinct up to around one-third of flank height, then gradually fainting and dividing around two-thirds of flank height into secondaries which, together with some 


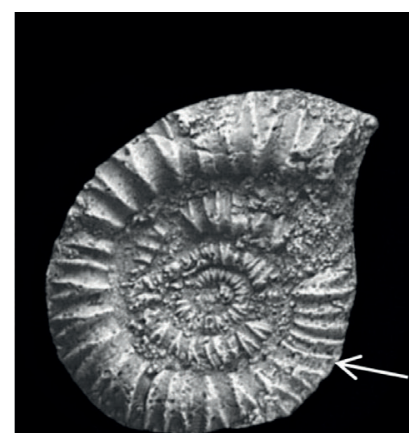

A

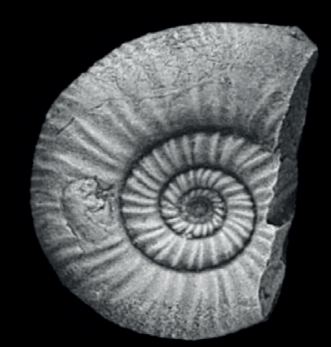

D

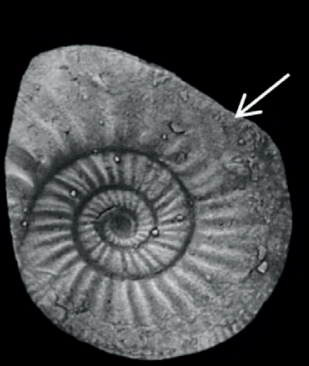

B

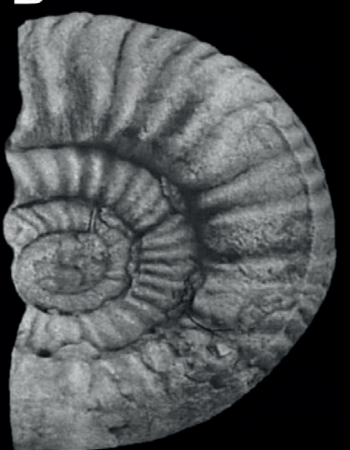

E

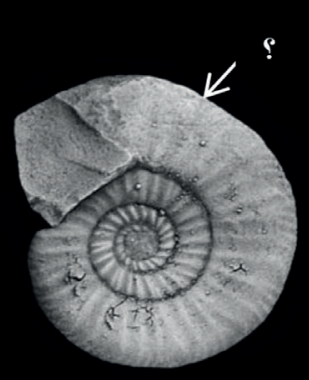

C

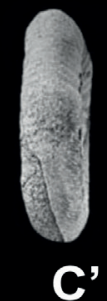

C'

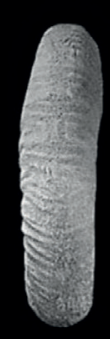

D'
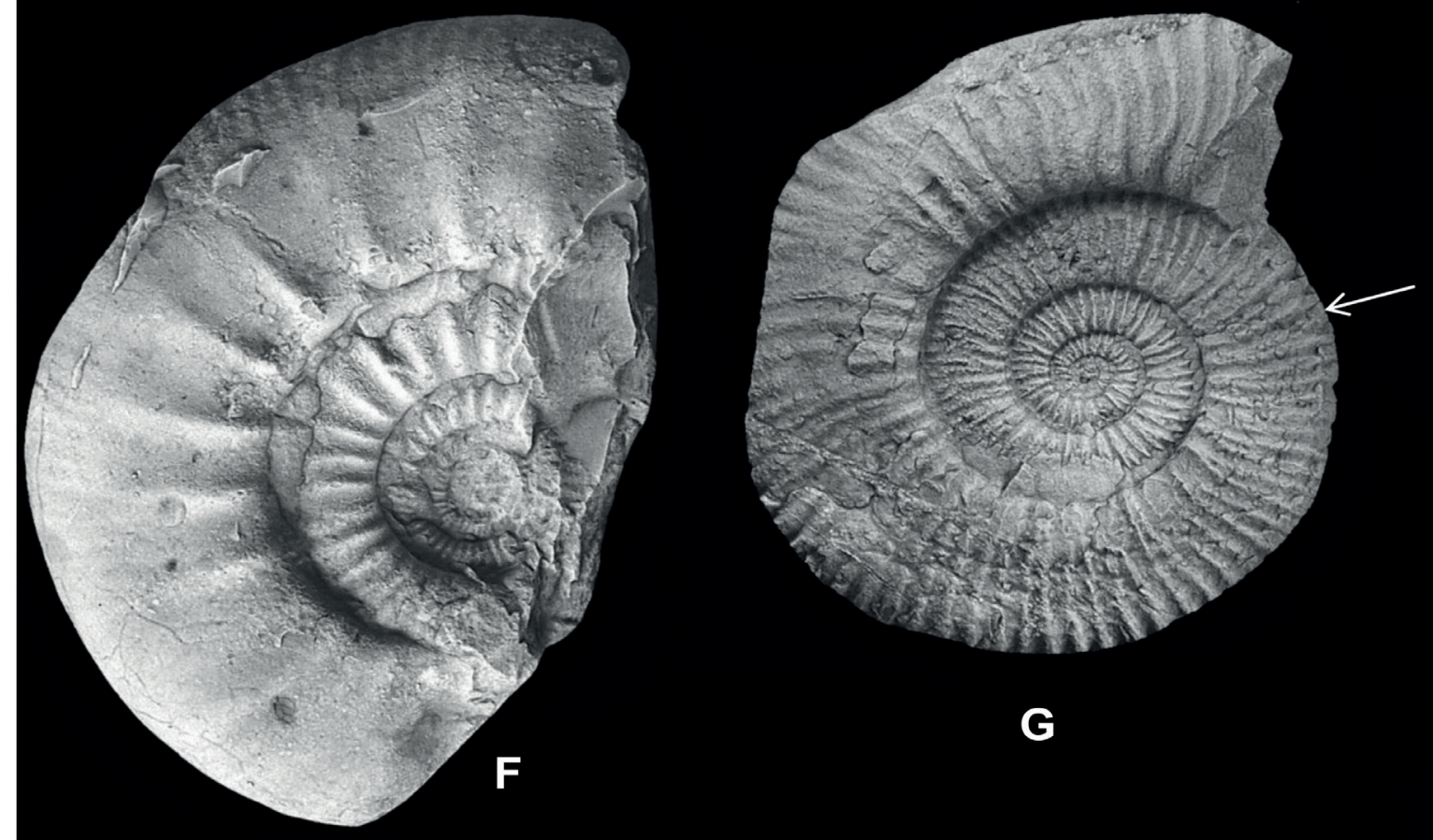

G

E' 


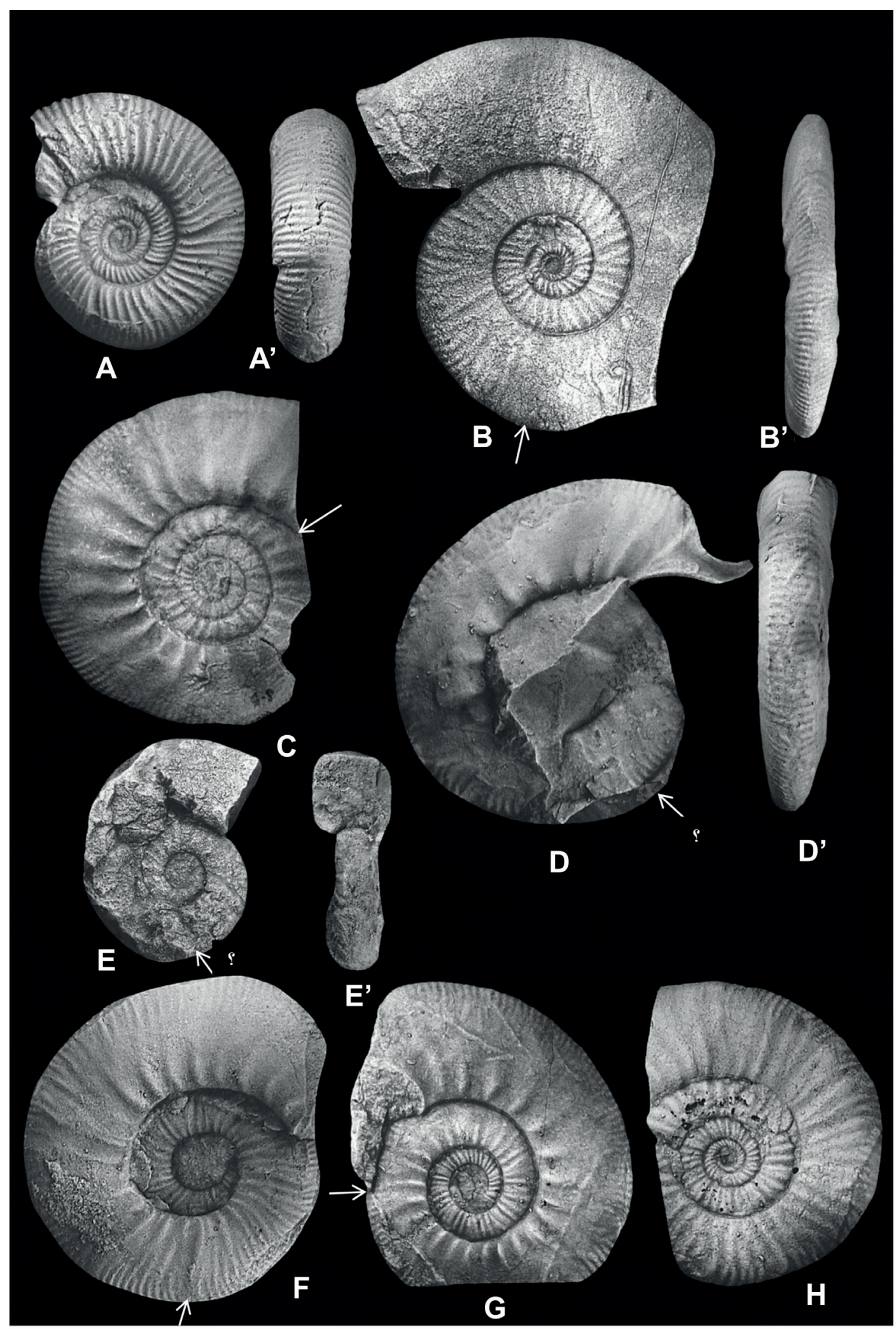

Figure 10. A-A', Grossouvria sp. (GZN2011I-S-3-53) with incomplete phragmocone, Tooy section, Middle Callovian, x1.5. B-B', Indosphinctes (Elatmites) sp. (GZN2011I-J-3-209), a phragmocone with incomplete body chamber, Golbini section, Middle Callovian. C, Indosphinctes (Elatmites) cf. revili (Mangold) (GZN2011I-J-3-224), a phragmocone with incomplete body chamber, Golbini section, Gracilis Zone. D-D', F-G, Flabellisphinctes (Flabellia) tsytovitchae (Mangold), Golbini section, Coronatum Zone. D-D', specimen GZN2011I J-3-226, a phragmocone with complete body chamber and lappet [m]. F, specimen GZN2011I-J-3-218, a phragmocone of a microconch with incomplete body chamber [m]. G, specimen GZN2011I-J-3-219, a phragmocone of a microconch with nearly complete body chamber [m]. E-E', Peltoceras sp. (GZN2011I-S-3-117), a phragmocone of a microconch with incomplete body chamber, Tooy section, Upper Callovian. H, Binatisphinctes (Okaites) cf. mosquensis (Siemiradzki) (GZN2011I-J-3-232) with incomplete phragmocone, Golbini section, Coronatum Zone. Dimensions in the text. 
intercalated ribs, continue towards the venter. Primary and secondary ribs equally coarse. Towards the aperture, primaries distant and whorl height increasing.

Remarks. Indosphinctes was propose d by Spath (1930) for a group of perisphinctids from the Callovian of Cutch and India. Stratigraphic distribution. The subgenus is known from the middle Callovian (Mangold, 1970b).

\section{Flabellisphinctes Mangold, 1970}

Subgenus Flabellia Mangold, 1970

Flabellisphinctes (Flabellia) tsytovitchae Mangold, 1970 [m]

(Figures 10D-D', F-G)

1938 Grossouvria curvicosta (Oppel) var. variabilis (Lahusen) - Pfaehler-Erath, p. 10, pl. 1, fig. 7.

1970b Flabellisphinctes (Flabellia) tuberosus sp. nov. Mangold, p. 196, pl. 15, fig. 3, pl. 16, figs. 3-4.

1970b Flabellisphinctes (Flabellia) tsytovitchae sp. nov. Mangold, p. 195, pl. 16, figs. 7-8.

2009 Flabellisphinctes (Flabellia) tsytovitchae Mangold Schlögl et al., p. 69, fig. 7(1).

Material. Seven specimens and three fragments from Golbini (GZN2011I-J-3-218-228), maximum diameter $72 \mathrm{~mm}$ and minimum $47 \mathrm{~mm}$, generally 63 to $69 \mathrm{~mm}$.

Dimensions (in mm).

\begin{tabular}{|c|c|c|c|c|c|c|}
\hline Specimens & $\mathrm{D}$ & $\mathrm{U} \%$ & $\mathrm{H} \%$ & W\% & $\mathrm{PR} / 2$ & $\mathrm{SR} / 2$ \\
\hline $\begin{array}{l}\text { GZN2011I-J-3-226 } \\
\text { (microconch with } \\
\text { lappet) }\end{array}$ & 69 & 41 & 31 & 20 & 9 & 51 \\
\hline $\begin{array}{l}\text { GZN2011I-J-3-218 } \\
\text { (microconch, } \\
\text { incomplete body } \\
\text { chamber) }\end{array}$ & 63 & 40 & 33 & 23 & 13 & 52 \\
\hline $\begin{array}{l}\text { GZN2011I-J-3-219 } \\
\text { (microconch, nearly } \\
\text { complete body } \\
\text { chamber) }\end{array}$ & 65 & 41 & 35 & 14 & 11 & - \\
\hline $\begin{array}{l}\text { GZN2011I-J-3-223 } \\
\text { (microconch, } \\
\text { incomplete body } \\
\text { chamber) }\end{array}$ & 72 & 35 & 37 & 22 & 10 & - \\
\hline $\begin{array}{l}\text { GZN2011I-J-3-227 } \\
\text { (microconch, } \\
\text { incomplete body } \\
\text { chamber) }\end{array}$ & 69 & 42 & 29 & 20 & 10 & - \\
\hline $\begin{array}{l}\text { GZN2011I-J-3-221 } \\
\text { (incomplete } \\
\text { phragmocone) }\end{array}$ & 51 & 43 & 33 & 16 & 13 & - \\
\hline $\begin{array}{l}\text { GZN2011I-J-3-228 } \\
\text { (incomplete } \\
\text { phragmocone) }\end{array}$ & 47 & 40 & 34 & 15 & 9 & - \\
\hline
\end{tabular}

Description. An adult microconch with complete body chamber and aperture (J-3-226), an adult specimen and microconch with nearly complete body chamber (J-3219), specimens (J-3-218, 223, 227) with incomplete body chambers, and specimens $(\mathrm{J}-3-221,228)$ with incomplete phragmocone, whorl cross-section oval, flanks flat, umbilicus shallow with the steep wall. Primaries on outer whorls coarse, strong and bullate mainly up to one-fourth of flank height and rarely up to mid-flank, then gradually vanishing. Primary ribs starting at the umbilical margin, dividing into fine and dense secondary ribs with some intercalated ribs at around three-fourth of flank height, and thereafter crossing the venter. Towards the aperture primaries are strong and distant.

Remarks. Mangold (1970b) introduced Flabellisphinctes (Flabellia) tuberosus and F. (Flabellia) tsytovitchae, mentioning as a distinguishing feature between the two species the more evolute nature and stronger ribs at the umbilical margin of the former. However, this difference is very small, and it appears more appropriate to regard the two as variants of one species, i.e. Flabellisphinctes (Flabellia) tsytovitchae. Specimen GZN2011I-J-5-226 exhibits on the last whorl a constriction with lappet and, therefore, is a microconch. Flabellisphinctes (Flabellia) tsytovitchae differs from F. (Flabellia) lineatus Mangold (1970), in being more evolute and having strong ribs at the umbilical margin.

Stratigraphic distribution. Upper part of middle Callovian, Coronatum Zone and Obductum Subzone (Mangold, 1970b), the species is recorded for the first time from Iran.

Family ASPIDOCERATIDAE Zittel, 1895 Subfamily PELTOCERATINAE Spath, 1924

Parawedekindia Schindewolf, 1925

Parawedekindia callomoni Sapunov, 1979

(Figure 9G)

1979 Parawedekindia callomoni sp. nov. - Sapunov, p. 154, pl. 47 , fig. 5 .

Material. One specimen from Tooy with diameter $82 \mathrm{~mm}$ (GZN2011I-S-3-58).

Dimensions (in mm).

\begin{tabular}{lcccccc}
\hline Specimen & $\mathrm{D}$ & $\mathrm{U} \%$ & $\mathrm{H} \%$ & $\mathrm{~W} \%$ & $\mathrm{PR} / 2$ & $\mathrm{SR} / 2$ \\
\hline $\begin{array}{c}\text { GZN2011I-S-3-58 } \\
\text { (incomplete body } \\
\text { chamber) }\end{array}$ & 80 & 45 & 34 & & 21 & 35 \\
\hline
\end{tabular}

Description. A specimen with incomplete body chamber, whorl cross-section oval, umbilicus shallow with a vertical wall. Primary ribs strong, coarse and rursiradiate, dividing near umbilical margin into two convex secondaries that cross straight over the venter. Ribs on inner whorls finer and denser than those on outer whorls. Primary and secondary ribs equally coarse.

Remarks. The present species is easily distinguished from other species of the genus by its fine and dense ribs on the inner whorls. The specimen is slightly smaller than the holotype of Sapunov (1979, pl. 47, fig. 5).

Stratigraphic distribution. According to Sapunov (1979), Parawedekindia callomoni occurs in the ?lower or ?middle Oxfordian. However, the present specimen comes from the Upper Callovian; the species is recorded for the first time from Iran. 
Peltoceras Waagen, 1871

Peltoceras sp.

(Figure 10E-E')

Material. One specimen from Tooy with diameter $42 \mathrm{~mm}$ (GZN2011I-S-3-117).

Dimensions (in mm).

\begin{tabular}{lcccc}
\hline Specimen & $\mathrm{D}$ & $\mathrm{U} \%$ & $\mathrm{H} \%$ & $\mathrm{~W} \%$ \\
\hline $\begin{array}{c}\text { GZN2011I-S-3-117 } \\
\text { (incomplete body } \\
\text { chamber) }\end{array}$ & 42 & 37 & 35 & 35 \\
\hline
\end{tabular}

Description. A specimen with incomplete body chamber, the poorly preserved specimen has a distinctly rectangular whorl cross-section and a broad venter. There are spines at the venter shoulder. The inner whorls are depressed and carry fine ribs. Stratigraphic distribution. The present specimens come from the upper Callovian.

\section{BIOSTRATIGRAPHIC AND PALEOBIOGEOGRAPHIC REMARKS}

The Callovian sedimentary succession in the Dalichai Formation is widely distributed and superbly exposed in the Alborz Mts., and contains an abundant fauna of Callovian ammonites. The latest Bathonian and early Callovian time interval is characterized by the presence of Macrocephalites and Bullatomorphites. In other words, the early Callovian (Bullatus and Gracilis zones) is indicated by the presence of Bullatimorphites (Bomburites) cf. microstoma and Macrocephalites (Macrocephalites) jacquoti for the Bullatus Zone and Reineckeia (Tyrannites) convex, Choffatia (Choffatia) sakuntala, and Indosphinctes (Elatmites) cf. revili for the Gracilis Zone.

The Bathonian-Callovian boundary is defined at the base of the Bullatus (jacquoti) Biohorizon. Infrazonal biostratigraphic units of the Bathonian-Callovian boundary interval established in the section are of the wide geographic distribution and high correlation potential in the Panboreal Superrealm, i.e., in European Russia, northern Caucasus, West Europe, East Greenland and in the Tethyan Super-realm, the adjacent European areas inclusive (Jacquoti Biohorizon) Kiselev et al. (2007).

The middle Callovian Anceps and Coronatum zones are documented, apart from Choffatia kontkiewiczi, Binatisphinctes cf. mosquensis, and Flabellisphinctes (Flabellia) tsytovitchae, in particular by some species of Hecticoceras, Rehmannia, and Reineckeia [e.g. Hecticoceras (Lunuloceras) cf. lunuloides, H. (Putealiceras) metomphalum, Rehmannia (Loczyceras) cf. hungarica, and R. (Loczyceras) sequanica]. The Middle Callovian contains numerous and diverse Ammonitina, composed mainly of Hecticoceratinae and Reineckeiidae. First, the presence of the subgenus Flabellia indicates the Coronatum Zone of upper middle Callovian Mangold (1970a). Second, C. (G.) kontkiewiczi kontkiewiczi is also typical of this zone, more precisely of the Baylei Subzone (although it appears already in the uppermost
Anceps Zone) (Schlögl et al., 2009). The stratigraphic ranges of hecticoceratid ammonites based on studies of Zeiss (1956), Lemine (1932), and Elmi (1967) mainly indicate a time span from the Anceps Zone up to the Athleta zones.

The latest Callovian and early Oxfordian represent one of the most dynamic intervals in the history of Jurassic Ammonoidea, and is characterized by one of the highest levels of mixing of Boreal, Submediterranean and even Mediterranean faunas (Page et al., 2009). The late Callovian is indicated by the presence of Reineckeia (Reineckeia) nodosa, indicative of the Athleta Zone, and of Pachyceras lalandei of the Lamberti Zone.

Quantitative and qualitative distributions show that Reineckeiidae and Hecticoceratinae include the $17 \%$ and 14\% respectively of the whole Callovian age ammonite fauna, the most abundant being in the Anceps Zone. Reineckeiidae and Hecticoceratinae accord with the biostratigraphic Subtethyan Province distribution (Sequeiros et al., 1986). Reineckeiidae and Oppeliidae are more abundant in the middle Callovian (Anceps Zone) than in the lower and upper Callovian in this area.

Paleobiogeographically, the Callovian ammonite fauna of the Dalichai Formation has a typical NorthwestTethyan character, and belong to the Submediterranean faunal province (Seyed-Emami et al., 2013), and are largely dominated by Phylloceratidae ammonites. These pelagic taxa that preferred open oceanic conditions are accompanied consistently by Perisphinctidae, Reineckeiidae, Oppeliidae (Hecticoceratinae), Macrocephalitidae, Tulitidae, Aspidoceratidae (Parawedekindia, Peltoceras).

On the other hand, this is supported by the occurrence of Submediterranean ammonites such as Macrocephalites, Pachyceras, and some cosmopolitan taxa such as Hecticoceras and Reineckeia. Furthermore, according to Page (2008), Schlögl et al. (2009) and Seyed-Emami \& Schairer (2011), the typical Mediterranean Reineckeiidae appears in large numbers and high diversity in the Alborz. Moreover, paleogeographic reconstructions place the Iranian platform at latitude of $30^{\circ} \mathrm{N}$ during the Jurassic, which is equivalant to European areas situated at the southern margin of Eurasia (e.g. Enay \& Cariou, 1997).

\section{FINAL REMARKS}

The most abundant ammonite families within the investigated sections of the Dalichai Formation are Phylloceratidae (40\%), Perisphinctidae (24\%), Reineckeiidae (17\%), Oppeliidae (14\%), Sphaeroceratidae (2\%), Macrocephlitidae (2\%), Tulitidae (1\%), and Pachyceratidae (1\%) (Figure 11). During the early Callovian, the number of ammonite taxa decreased, which can be related to a sea-level fall. In the middle Callovian, the families Phylloceratidae, Oppeliidae, and Reineckeiidae are most abundant. Besides numerous taxa of these families, also Perisphinctidae occur. This pattern agrees well with the Jurassic global sealevel curve (e.g. Hallam, 2001), which indicates a major eustatic sea-level rise during the middle Callovian. In the 


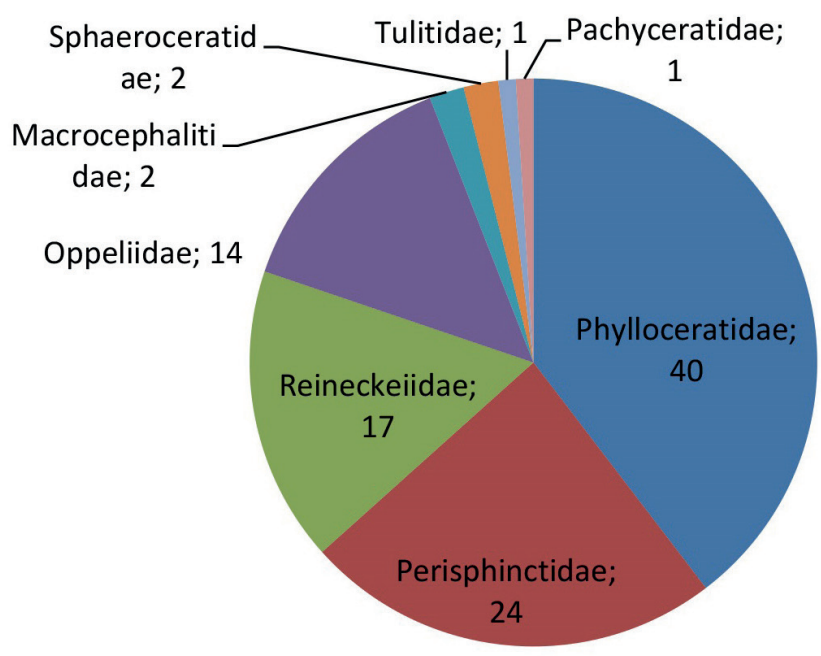

Figure 11. Relative abundances of Callovian ammonite families at the studied sections.

late Callovian, in contrast, the diversity and number of the ammonite families Reineckeiidae (Reineckeia nodosa, two specimens), Pachyceratidae (Pachyceras, 1 specimen), Aspidoceratidae (Parawedekindia, one specimen; Peltoceras, one specimen) is reduced, indicating again a sea-level fall (e.g. Seyed-Emami et al., 2013).

\section{ACKNOWLEDGMENTS}

I would like to thank the staff of the former "Institut für Paläontologie" of Erlangen University (F.T. Fürsich) who provided the opportunity for me to study in Würzburg and Erlangen. I would like to thank K. Seyed-Emami, Tehran; M. Wilmsen, Dresden; and G. Dietl, Stuttgart, for useful discussions. I would like to extend my thanks to H. Schönig, B. Schroeder, and M. Strifler, Würzburg, for photographic work. The present study was financially supported by the "Deutsche Akademische Austauschdienst (DAAD)", which I gratefully acknowledge. My appreciation goes also to M.T. Korehie, Director of the Geological Survey of Iran (GSI) and M.R. Ghasemi former Geological Deputy of GSI for their help and encouragement and for supporting the fieldwork in Iran.

\section{REFERENCES}

Andal, D.R.; Esguerra, J.S.; Hashimoto, W.; Reyes, B.P. \& Sato, T. 1968. The Jurassic Mansalay Formation, southern Mindoro, Philippines. Contributions to the Geology and Palaeontology of South east Asia. Geology and Palaeontology of Southeast Asia, 4:179-197.

Arkell, W.J. 1951-1958. A monograph of the English Bathonian ammonites. London, Palaeontographical Society, 264 p. (Monographs 104-108, 110-112).

Arkell, W.J.; Kummel, B. \& Wright, C.W. 1957. Mesozoic Ammonoidea. In: R.C. Moore (ed.) Treatise on Invertebrate Paleontology. Part L, Mollusca 4, Cephalopoda, Ammonoidea, The Geological Society of America, p. 80-465.

Assereto, R. 1968. The Jurassic Shemshak Formation in central Elburz (Iran). Rivista Italiana di Paleontologia e Stratigrafia, 72:1133-1182.
Bayle, E. 1878-1979. Fossils principaux des terrains. Memory Explorer Carte, 4:23-99.

Besnossov, N.V. 1958. Jurassic Ammonites from the Kaukasus and Crimea. Vestnik Moskovskogo Universiteta, 13:109-117.

Bonarelli, G. 1893. Hecticoceras novum genus Ammonidarum. Bolletino della Società Malacologia Italiana, 18:73-108.

Bourquin, J. 1968. Les Reineckeides. Besançon, 1'Université Besançon, $169 \mathrm{p}$.

Buckman, S.S. 1905. On certain genera and species of Lytoceratidae. Quarterly Journal of the Geological Society of London, 61:142154. doi:10.1144/GSL.JGS.1905.061.01-04.11

Buckman, S.S. 1909-1930. Yorkshire type ammonites. Buckinghamshire, Wheldon \& Wesley, $541 \mathrm{p}$.

Cariou, E. 1984. Les Reineckeiidae (Ammonoidea, Callovien) de la Tethys occidentales. Dimorphisme et evolution. Etude à partir des gisements du centre-ouest de la France. Lyon, Laboratoires de Géologie Lyon, 599 p. (Bulletin 8).

Cariou, E. \& Krishna, J. 1988. The Tethyan Reineckeiinae of Kachchh and Jaisalmer (West India), systematic, biostratigraphic and biogeographic implications. Palaeontographica Abteilung A, 203:149-170.

Conze, R.; Errenst, C. \& Mensink, H. 1984. Die ammoniten des Ober-Callovium bis Unter Kimmeridgium in den nordwest Lichen Keltiberischen Ketten. Palaeontographica Abteilung $A, \mathbf{1 8 3}: 162-211$

d'Orbigny, A. 1842-1850. Paleontologie francaise, terrains jurassiques - I, Cephalopodes. Chez l'auteur, $642 \mathrm{p}$.

Dietl, G. 1994. Der hochstetteri-Horizont - ein AmmonitenfaunenHorizont (Discus-zone, Ober-Bathonium, Dogger) aus dem Schwäbischen Jura. Stuttgart, Staatliches Museum für Naturkunde Stuttgart, 39 p. (Bulletin 202).

Dietl, G. \& Gygi, R. 1998. Die Basis des Callovium (Mittlerer Jura) bei Liesberg BL, Nordschweiz. Eclogae Geologicae Helvetiae, 91:247-254.

Dietl, G.; Rosswog, E. \& Loerrach, R. 2012. Die ammoniten-fauna des calloviense-Horizonts (Callovien-se-Zone, Unter-Callovium, Mitteljura) von Kandern (Süd- baden, SW-Deutschland). Jahreshefte der Gesellschaft für NaturkundeWürttemberg, 168:5-28.

Dietze, V.; Seyed-Emami, K. \& Raoufian, A. 2014. Morphoceras Douvillé, 1880 and Ebrayiceras Buckman, 1920 from the Dalichai Formation (Lower Bathonian) North and Northeast of Damghan (Northeast Alborz), Iran. Zitteliana A, 54:15-22.

Douvillé, R. 1912. Etudes sur les Cardioceratides de Dives, Villerssur-Mer et quelques autres gisements. Paris, Société Géologique de France, 77 p. (Mémoires 48).

Elmi, S. 1967. Le Lias supérieur et le Jurassique moyen de l'Ardèche. Lyon, Laboratoires de Géologie de la Faculté des Sciences, 845 p. (Documents 19).

Enay, R. \& Cariou, E. 1997. Ammonite faunas and palaeobiogeography of the Himalayan belt during the Jurassic: initiation of a late Jurassic austral ammonite fauna. Palaeogeography, Palaeoclimatology, Palaeoecology, 134:1-38. doi:10.1016/ S0031-0182(96)00157-5

Fischer, V.W. 1843. Revue des fossiles du Gouvernement de Moscou. Société Naturelle, $145 \mathrm{p}$.

Fürsich, F.T.; Wilmsen, M.; Seyed-Emami, K. \& Majidifard, M.R. 2009. Lithostratigraphy of the Upper Triassic-Middle Jurassic Shemshak Group of northern Iran. In: M.-F. Brunet; M. Wilmsen \& J.W. Granath (eds.) South Caspian to central Iran basins, London, Geological Society of London, p. 129-160 (Special Publications 312). doi:10.1144/SP312.6

Gemmellaro, G.G. 1872. Sopra i fossili della Zona con Aspidoceras acanthicum, Opp. sp. di Burgilanumi, presso Favara, provinci di Girgenti. Giornali di Scienze Naturale Econoniche, 8:137-159 . 
Hahn, W. 1971. Die Tulitidae S. Buckman, Sphaeroceratidae S.Buckman un Clydoniceratidae S. Buckman (Ammonoidea) des Bathoniums (Brauner Jura) im südwestdeutschen Jura. Jahreshefte des Geologischen Landesamtes Baden, Württemberg, 13:55-122.

Hallam, A. 2001. A review of the broad pattern of Jurassic sea-level changes and their possible causes in the light of current knowledge. Palaeogeography, Palaeoclimatology, Palaeoecology, 167:23-37. doi:10.1016/S0031-0182(00)002297

Hillebrandt, A. \& Groeschke, M. 1975. Ammoniten aus dem Callovium/Oxfordium Grenzbereich von Nordchile. Berlin, Selbstverlag Fachbereich Geowissenschaften, 40 p. (Bulletin 169).

Hoffmann, R. 2010. New insights on the phylogeny of the Lytoceratoidea (Ammonitina) from the septal lobe and its functional interpretation. Revue de Paléobiologie, 29:1-156.

Hyatt, A. 1900. Cephalopoda. In: K.A. Zittel (ed.) Text-book of palaeontology, Eastman C.R., p. 502-592.

Jeannet, A. 1951. Stratigraphie und Palaeontologie des oolitischen Eisenerzlagers von Herznach und seiner Umgebung. Zürich, Beiträge zur geologischen Karte der Schweiz, 240 p. (Bulletin 13).

Jeannet, A. 1954. Die Macrocephaliten des Callovium von Herznach (Aargau). Eclogae Geologicae Helvetiae, 47:223-268.

Joly, B. 1976. Les Phylloceratidae malgaches au Jurassique. Généralites sur les Phylloceratidae et quelques Juraphyllitidae. Lyon, Laboratoires de Géologie Lyon, 471 p. (Documents 67).

Kilian, W. 1899. Déscription géologique de la Montagne de Lure (Basses-Alpes). Paris, Université de Paris, 458 p.

Kiselev, D.N. \& Rogov, M.A. 2007. Stratigraphy of the BathonianCallovian boundary deposits in the Prosek Section (Middle Volga Region). Article 1. Ammonites and infrazonal biostratigraphy. Stratigraphy and Geological Correlation, 15:485-515. doi:10.1134/S0869593807050036

Kuhn, O. 1939. Die Ammoniten des fränkischen Calloviums. Nova Acta Leopoldina, 6:451-532.

Lahusen, I. 1883. Die Fauna der Jurassischen Bildungen des Rjasanschen Gouvernements. Saint Petersburg, Comite Geologique, 94 p. (Memories 1).

Lee, G.W. 1905. Contribution à l'étude stratigraphique et paléontologique de la Chaine de la Faucille. Liebefeld, Société Paléontologique Suisse, 91 p. (Mémoires 32).

Lemoine, E. 1932. Essai sur l'évolution du genre Hecticoceras dans le Callovien de la Chaine du Montdu-Chat. Deux nouvelles espèces d'Horioceras. Lyon, Laboratoire de Géologie de la Faculté des Sciences de Lyon, 527 p. (Travaux 19).

Lemoine, P. 1910. Ammonites du Jurassique supérieur du Cercle d'Analalava (Madagascar). London, Masson, 52 p. (Annales de Paléontologie 5).

Lominadze, T.A. 1975. The Calloway Hecticoceratinae of the northern Caucasus. 99 p.

Majidifard, M.R. 2003. Biostratigraphy, lithostratigraphy, ammonite taxonomy and microfacies analysis of the Middle and Upper Jurassic of northeastern Iran. University of Wuerzburg, Ph.D. Thesis, $201 \mathrm{p}$.

Majidifard, M.R. 2008. Stratigraphy and facies analysis of the Dalichai and Lar formations (Middle-Upper Jurassic) of NNE Iran. Beringeria, 39:3-49.

Mangold, C. 1970a. Stratigraphie des étages bathoniens et callovien du Jura méridional. Lyon, Laboratoires de Géologie Lyon, 376 p. (Documents 41).

Mangold, C. 1970b. Les Perisphinctidae (Ammonitina) du Jura méridional au bathonien et au Callovien. Lyon, Laboratoires de Geologie Lyon, 246 p. (Documents 41).

Meledina, S.V. 1987. Ammonites and zonal stratigraphy of the Callovian of subboreal regions of the USSR. Moskva, Academy of Sciences of the USSR, Institute of Geology and Geophysics, $181 \mathrm{p}$.

Mitta, V. 2009. Genus Eckhardites Mitta (Cardioceratidae, Ammonoidea) from the Lower Callovian of the Subboreal Jurassic. Paleontological Journal, 43:50-58. doi:10.1134/ S0031030109010055

Neumayr, M. 1875. Die Ammoniten der Kreide 1llld die Systematik der Ammonitiden. Zeitschrifl der Deutschen Geologischen Gesellschafl, 27:854-892.

Page, K.N. 2008. The evolution and geography of Jurassic ammonoids. Proceedings of the Geologists' Association, 119:35-57. doi:10.1016/S0016-7878(08)80257-X

Page, K.N.; Melendez, G. \& Wright, J. 2009. The ammonite fauna of the Callovian-Oxfordian boundary interval in Europe and their relevance to the estalishment of the Oxfordian GSSP. Volumina Jurassica, 7:89-99.

Parona, C.F. \& Bonarelli, G. 1895. Sur la fauna du Callovien inférieur (Chanazien) de Savoie. Savoie, Memoire de la Academie Science Savoie, 183 p.

Pfaehler-Erath, I. 1938. Sur quelques Grossouvria et Choffatia du Callovien de Chezery (Jura francais). Liebefeld, Société Paléontologique Suisse, 29 p. (Mémoires 60).

Quenstedt, F.A. 1845-1849. Petrefaktenkunde Deutschlands, Die Cephalopoden. Fues, $580 \mathrm{p}$.

Quenstedt, F.A. 1858. Der Jura. Tübingen. Laupp, 842 p.

Quenstedt, F.A. 1887-1888. Die Ammoniten des Schwäbischen Jura. E. Schweizerbart, p. 817-944 (1887), p. 944-1140 (1888).

Rangheard, Y. 1961. Etude paléontologique des représentants du genre Hecticoceras du Callovien du Jura Franc-Comtois. Annales scientifiques de l'Université de Besançon, Série Géologie, 14:135-178.

Reinecke, D.J.C.M. 1818. Maris protagaei Nautilos et Argonautas vulgo Cornua Ammonis. Coburgi. Ahl, 90 p.

Rocha, R. 1976. Tiuloestudo estratigrafico e paleontologico do Jurassico do Algarve occidental. Centro de Estratigrafia e Paleobiologia, Universidade Nova de Lisboa, Ciências da Terra, $178 \mathrm{p}$.

Rollier, L. 1922. Phylogeny des ammonoïdes. Eclogae Geologicae Helvetiae, 27:358-360.

Sapunov, I. 1979. Les Fossiles de Bulgarie III 3. Jurassique Supérieur, Ammonoidea. Sofia, Academie Bulgarie des Sciences, $263 \mathrm{p}$.

Sasonov, N.T. 1961. Jurskie otlozenija centralnych oblastej russkoj platformy. Leningrad, $155 \mathrm{p}$.

Schairer, G.; Seyed-Emami, K.; Fürsich, F.T.; Senowbari, B.; Aghanabati, S.A. \& Majidifard, M.R. 2000. Stratigraphy, facies analysis and ammonite fauna of the Qaleh Dokhtar Formation (Middle-Upper Jurassic) at the type locality west of Boshrouyeh (east-central Iran). Neues Jahrbuch für Geologie und Paläontologie - Abhandlungen, 216:35-66. doi:10.1127/ njgpa/216/2000/35

Schairer, G.; Seyed-Emami, K. \& Zeiss, A. 1991. Ammoniten aus der oberen Dalichai Formation (Callov) östlich von Semnan (SEAlborz, Iran). Mitteilungen der Bayerischen Staatssammlung für Paläontologie und Historische Geologie, 31:47-67.

Schairer, G. \& Zeiss, A. 1992. First record of Callovian ammonites from West Kalimantan (Middle Jurassic, Kalimantan Barat, Borneo, Indonesia). BMR Journal of Australian Geology \& Geophysics, 13:229-236. 
Schindewolf, O.H. 1925. Entwurf einer Systematik der Perisphincten. Neues Jahrbuch für Mineralogie, Geologie und Paläontologie, 52:309-343.

Schirardin, J. 1956. Le Callovien du sondage HNI de Blo-delsheim (Haut-Rhin). Bulletin del Service de la Carte geologique de Alsace et le Lorraine, 9:39-84.

Schlegelmilch, R. 1985. Die Ammoniten des süddeutschen Doggers, ein Bestimmungsbuch für Fossiliensammler und Geologen. Heidelberg, Spektrum Akademischer Verlag, 283 p. doi:10.1007/978-3-8274-3105-9

Schlögl, J.; Mangold, C.; Tomašových, A. \& Gole, M. 2009. Early and Middle Callovian ammonites from the Pieniny Klippen Belt (Western Carpathians) in hiatal successions: unique biostratigraphic evidence from sediment-filled fissure deposits. Neues Jahrbuch für Geologie und Paläontologie - Abhandlungen, 252:55-79. doi:10.1127/0077-7749/2009/0252-0055

Sengör, A.M.C. 1990. A new model for the Paleozoic-Mesozoic tectonic evolution of Iran and implication for Oman. In: A.H.F. Robertson; M.P. Searle \& A.C. Ries (eds.) The Geology and tectonic of the Oman region, London, Geological Society London, p. 797-831 (Special Publication 49). doi:10.1144/GSL. SP.1992.049.01.49

Sequeiros, L.; Cariou, E. \& Thierry, J. 1986. Posicion bioestratigrafica $\mathrm{y}$ datos paleobiogeograficos de los Reineckeiinae (Ammonitina) del Calloviense de Aragon (Cordillera Iberica, Espana). Revista Espanola de Paleoontologica, 1:73-84.

Seyed-Emami, K. 1975. Jurassic-Cretaceous Boundary in Iran. American Association of Petroleum Geologists, 59:231-238.

Seyed-Emami, K. \& Alavi-Naini, M. 1990. Bajocian stage in Iran. Memorie Decriptive Della Carta Geologica D'Italia, 40:215-221.

Seyed-Emami, K. \& Schairer, G. 2011. New Middle and Upper Jurassic ammonites from the Binalud Mountains (Mashhad region, NE Iran). Neues Jahrbuch für Geologie und Paläontologie - Abhandlungen, 261:373-380. doi:10.1127/00777749/2011/0181

Seyed-Emami, K.; Schairer, G. \& Aghanabati, S.A. 1997. Ammoniten aus der Baghmshah-Formation (Callov,Mittlerer Jura) NW Tabas (Zentraliran). Mitteilungen der Bayerischen Staatssammlung für Paläontologie und Historische Geologie, 37:27-40.

Seyed-Emami, K.; Schairer, G., Aghanabati, S.A. \& Fazl, M. 1991. Ammoniten aus dem Bathon der Gegend von Tabas - Nayband (Zentraliran). Münchner Geowissenschaftliche Abhandlungen, 19:65-100.

Seyed-Emami, K.; Schairer, G. \& Alavi-Naini, M. 1989. Ammoniten aus der unteren Dalichai-Formation (Unterbathon) östlich von Semnan (SE-Alborz, Iran). Münchner Geowissenschaftliche Abhandlungen, 15:79-91.

Seyed-Emami, K.; Schairer, G.; Fürsich, F.T.; Wilmsen, M. \& Majidifard, M.R. 2002. Reineckeiidae (Ammonoidea) from the Callovian (Middle Jurassic) of the Shotori Range (EastCentral Iran). Neues Jahrbuch für Geologie und Paläontologie - Abhandlungen, 225:184-192.

Seyed-Emami, K.; Schairer, G.; Raoufian, A. \& Shafeizad, M. 2013. Middle and Late Jurassic ammonites from the Dalichai Formation west of Shahrud (East Alborz, North Iran). Neues Jahrbuch für Geologie und Paläontologie - Abhandlungen, 267:43-66. doi:10.1127/0077-7749/2012/0296

Seyed-Emami, K.; Schairer, G. \& Zeiss, A. 1991. Ammoniten aus der oberen Dalichai-Formation (Callov) östlich von Semnan (SEAlborz, Iran). Mitteilungen der Bayerischen Staatssammlung für Paläontologie und Historische Geologie, 31:47-67.

Seyed-Emami, K.; Schairer, G. \& Zeiss, A. 1995. Ammoniten aus der Dalichai-Formation (Mittlerer bis Oberer Jura) und der LarFormation (Oberer Jura) N Emamzadeh Hashem (Zentralalborz,
Nordiran). Mitteilungen der Bayerischen Staatssammlung für Paläontologie und Historische Geologie, 35:39-52.

Shevyrev, A.A. 1960. Ontogenetic development of some upper Jurassic ammonites. Bulletin de la Société des Naturalistes de Moscou, 35:69-78.

Siemiradzki, J. 1894. Neue Beiträge zur Kenntniss der Ammonitenfauna der polnischen Eisenoolithe. Zeitschrift der Deutschen geologischen Gesellschaft, 46:501-536.

Siemiradzki, J. 1898-1899. Monographische Beschreibung der Ammonitengattung Perisphinctes. Palaeontographica, 45:69-296.

Spath, L.F. 1924. On the ammonites of the Speeton clay and the subdivisions of the Neocomian. Geological Magazine, 61:73-89. doi: $10.1017 /$ S0016756800083588

Spath, L.F. 1925. Jurassic Cephalopoda from Madagascar. Bulletins of American Paleontology, 2:141-170.

Spath, L.F. 1927-1933. Revision of the Jurassic cephalopod fauna of Kachh (Cutch). Kolkata, Geological Survey of India, 945 p. (Memoirs 9).

Steiger, R. 1966. Die Geologie der west-Firuzkuh-Area (Zentralelburz, Iran). Zürich, Geologischen Institut der E.T.H. und Universität Zürich, 145 p. (Mitteilungenaus 68).

Steinmann, G. 1890. Cephalopoda. In: G. Steinmann \& L. Döderlein (eds.) Elemente der Paläontologie, Engelmann, p. 344-475.

Stremoukhoff, D. 1923. Les ammonites de la montagne Eguer-Oba près de Koktebel (2e art.). Bulletin of the Moscow Branch of the Geological Committee, 1:267-286.

Thierry, J. 1978. Le genre Macrocephalites, Callovian inferieur (ammonites jurassique moyen). Dijon, L'universite de Dijon, 490 p. (Mémoires Géologiques 4).

Thierry, J.; Cariou, E.; Elmi, S.; Mangold, C.; Marchand, D. \& Rioult, M. 1997. Callovien. In: E. Cariou \& P. Hantzpergue (eds.) Biostratigraphie du Jurassique ouest-Européen et Méditerranéen, Centre de Recherches Elf Exploration et Production, p. 63-78.

Till, A. 1907. Die Cephalopodengebisse. Jahrbuch der Kaiserlichköniglichen Geologischen Reichsanstalt Wien, 57:535-682.

Till, A. 1910-1911. Die Ammonitenfauna des Kelloway von Vilany (Ungarn). Beiträge zur Paläontologie und Geologie Österrreich,Ungarns und des Orients, 23:251-272.

Tsytovitch, X.D. 1911. Hecticoceras du Callovien de Chezery. Liebefeld, Société Paléontologique Suisse, p. 142-198 (Mémoires 37).

Waagen, W. 1873-1875. Jurassic fauna of Kutch; Cephalopoda. Kolkata, Geological Survey of India, 247 p. (Memoirs 9).

Westermann, G.E.G. 1958. Ammoniten fauna und Stratigraphie des Bathonium NW Deutschland. Beihefte zum Geologischen Jahrbuch, 32:1-103.

Zeiss, A. 1956. Hecticoceras und Reineckeia im Mittel-und OberCallovien von Blumberg (Südbaden). München, Bayerische Akademie der Wissenschaften München, 101 p. (Bulletin 80).

Zeiss, A. 1959. Hecticoceratinae (Ammonoidea jurassica). In: W. Quenstedt (ed.) Fossilium Catalogus I: Animalia, Uitgeverij Dr. W. Junk's, 143 p.

Zittel, K.A. 1884. Cephalopoden. In: R. Oldenbourg (eds.) Handbuch der Paläontologie, Druck und Verlag von R, p. 329-522.

Zittel, K.A. 1895. Grundzüge der Paläontologie (Paläozoologie). Munich, Oldenbourg, $971 \mathrm{p}$.

Received in 12 November, 2016; Accepted in 23 November, 2017. 